\title{
Changes in paleo-circulation and the distribution of ammonite faunas at the Coniacian-Santonian transi- tion in central Poland and western Ukraine
}

\author{
ZBYSZEK REMIN ${ }^{1}$, MICHAŁ GRUSZCZYNSSKI and JIM D. MARSHALL ${ }^{2}$ \\ ${ }^{1}$ Institute of Geology, University of Warsaw, Al. Żwirki i Wigury 93, 02-089 Warszawa, Poland. \\ E-mail: zbyh@uw.edu.pl \\ ${ }^{2}$ Department of Earth, Ocean and Ecological Sciences, University of Liverpool, Liverpool L69 3GP, United Kingdom
}

\section{ABSTRACT :}

Remin, Z., Gruszczyński, M. and Marshall, J.D. 2016. Changes in paleo-circulation and the distribution of ammonite faunas at the Coniacian-Santonian transition in central Poland and western Ukraine. Acta Geologica Polonica, 66 (1), 107-124. Warszawa.

Ammonite distribution patterns and carbon and oxygen stable isotopes from the Lipnik-Kije (Poland) and Dubovcy (Ukraine) sections allow us to propose a model of sea water paleo-circulation in central Europe for the ConiacianSantonian interval. The tectonic evolution of the south-eastern part of Poland, and expansion of the Krukienic Island areas, appears to have been one of the most important factors affecting paleotemperatures and the distribution of ammonite faunas in the shallow, epicontinental sea in this part of Europe. In the Lipnik-Kije section, low-latitude Tethyan ammonites, especially of the genera Nowakites, Parapuzosia and Saghalinites, are mixed with the cold water loving ammonite genus Kitchinites in the Lower Santonian. In the Dubovcy section (western Ukraine), Tethyan ammonites disappear abruptly in the earliest Santonian, giving place to temperate ammonites of the Kitchinites group in the early Early Santonian and to Boreal belemnites of the genus Gonioteuthis in the Middle and Late Santonian. Despite evidence for the effects of diagenesis in both sections, bulk-rock $\delta^{18} \mathrm{O}$ records from the limestones support higher seawater paleotemperatures in the Polish sea and cooler conditions in the western Ukraine.

The proposed paleo-circulation model and paleotemperature distribution across Europe is supported independently by changes in faunal and nannoflora evidence (ammonites, foraminifera and nannoplankton), and rather unexpectedly with the bulk $\delta^{18} \mathrm{O}$ data. These data allow the recognition of the end-Coniacian-Early Santonian cooling event, resulting from cold currents flowing from the north, which is traceable, with different magnitude, in several European sections.

Facies changes in both sections are related to the input of terrigenous material, and linked to Subhercynian tectonic movements which affected the eastern (Ukrainian) and central (Holy Cross) segment of the Mid Polish Trough at different times. Uplift and sediment input moved westwards through time. Clastic input is detectable at the Coniacian-Santonian boundary in the Ukrainian segment. Similar facies changes reached the Holy Cross segment in Poland distinctly later, somewhen in the Middle Santonian. It is likely that tectonics together with paleo-circulation changes markedly restricted or even cut-off the western Ukraine area from Tethyan ocean influences in the Early Santonian.

Key Words: Coniacian-Santonian transition; Paleogeography; Paleo-circulation; Ammonites; Carbon and oxygen stable isotopes. 


\section{INTRODUCTION}

The impetus for the present study arose from the discovery of an unexpectedly high abundance of the Tethyan warm-water ammonites as far north as the Lipnik-Kije section in the Coniacian-Santonian succession in Poland (Remin 2010), an area generally included in the cool-water Boreal Realm. This led to the hypothesis that warm ocean currents reached far north into central Poland. The presence of mixed ammonite assemblages from the Tethyan and Boreal realms in this area enables correlation of previously uncorrelatable sections of northern (e.g. Münsterland Basin, Germany) and southern Europe (e.g. Corbiéres, France; Remin 2010).

Although the correlation of the Coniacian-Santonian boundary interval by means of stable isotope curves is less clear than for some other parts of the Upper Cretaceous (compare Jarvis et al. 2006), it is still possible as exemplified below. This study provides two new carbon isotope curves encompassing the ConiacianSantonian boundary interval and relates them to ideas concerning distribution of ammonite fauna, ocean paleocirculation and paleogeographic architecture.

Isotopic data, reported here, infer paleotemperatures for the Polish Sea (Lipnik-Kije section) that are anomalously high: higher than for the area of East Kent (UK), a part of Boreal Atlantic, and perhaps higher than those inferred for Spain, which was a part of northern Tethys Ocean (Jenkyns et al. 1994; Lamolda and Paul 2007). The Dubovcy section in western Ukraine has a paleoposition which predisposes it for a comparative investigation. Paleogeographically, the Dubovcy section is located between Lipnik-Kije (central Poland) and the Hateg section (SW Romania) where inferred paleotemperatures derived from bulk-rock $\delta^{18} \mathrm{O}$ seem to be the highest (Melinte-Dobrinescu and Bojar 2010). The initial assumption was that western Ukraine in Coniacian-Santonian times should be characterized by intermediate paleotemperatures. This assumption, however, is not backed up by either the ammonite distribution pattern or bulk rock oxygen isotopic data, leading us to propose a new model of ocean paleo-circulation.

This study has three main aims. First is to report and interpret the carbon and oxygen stable isotope records of the Coniacian-Santonian boundary intervals in the Lipnik-Kije sedimentary succession (SW Mesozoic margin of the Holy Cross Mts [HCM]), Central Poland and the Dubovcy succession in western Ukraine. Using the biostratigraphic datum level defined by the FAD [First Appearance Datum] of Cladoceramus undulatoplicatus (Roemer, 1852) we are able to correlate the carbon curves with other sections, including the currently proposed GSSP for the base of the Santonian Stage at Olazagutia, Navarra, Spain (Lamolda et al. 2014; Lamolda and Paul 2007) and former candidate sections including the Ten Mile Creek section, Lancaster, Dallas County, north Texas, USA (Gale et al. 2007) and the Chalk succession in England (Jarvis et al. 2006). Second, on a regional scale, is to provide an explanation of the abundance of both the Tethyan and Boreal ammonite faunas observed in the Lipnik-Kije section in re-

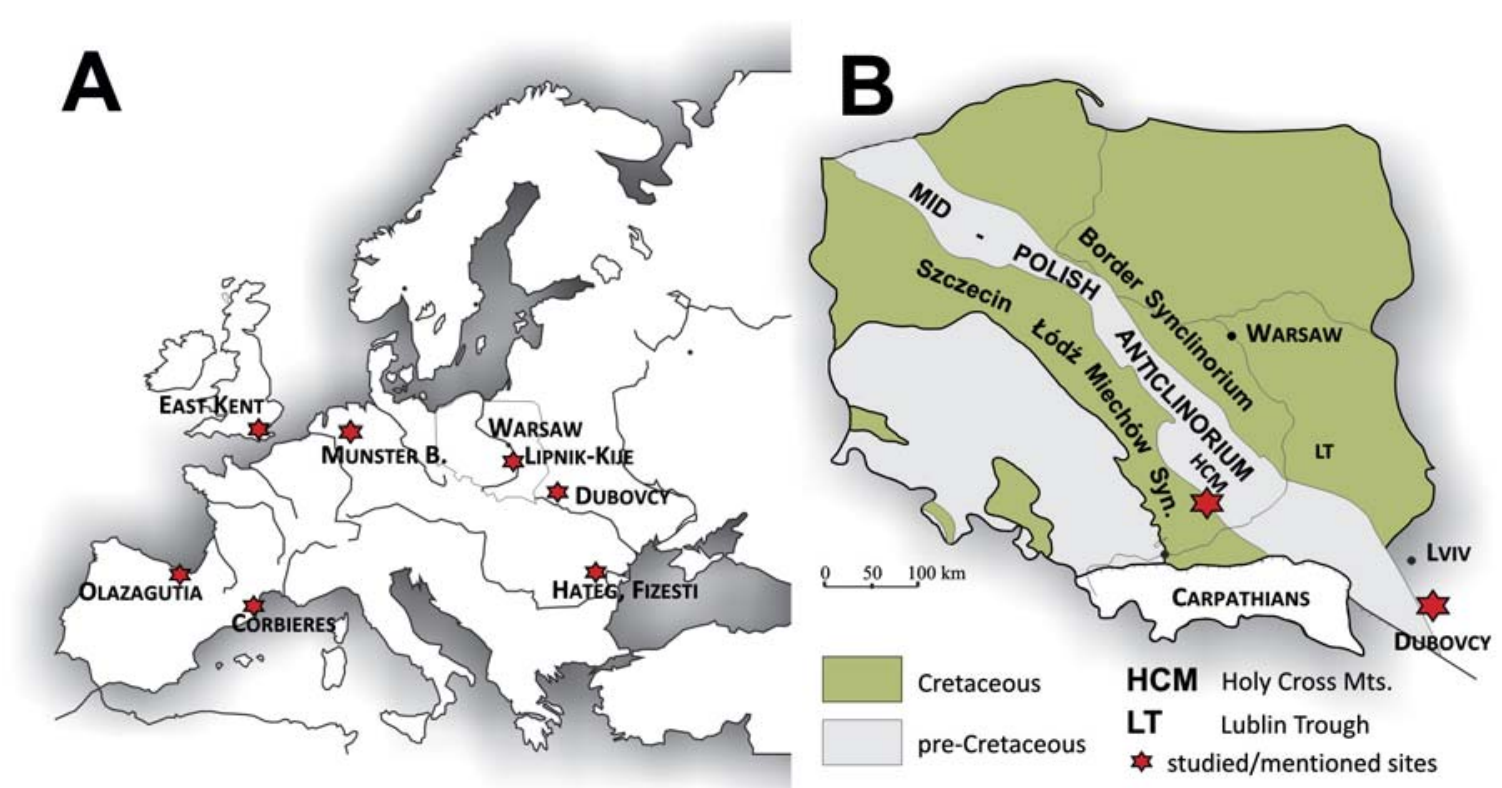

Text-fig 1. A - location of sites mentioned in the text; B - simplified geological and tectonic sketch map of Poland (without the Cenozoic cover; after Pożaryski 1974) with the location of the Lipnik-Kije and Dubovcy sections in relation to the Mid-Polish Anticlinorium 
lation to temperatures inferred from the ammonite distributions and the oxygen stable isotope record including the here recognized Coniacian-Santonian Cooling Event $[=\mathrm{CSCE}]$. Third, we aim to discuss other factors that might have controlled the rather unexpected paleotemperature distribution in central Europe. And finally, based on the above, we propose a coherent model of paleo-circulation in this part of Europe for the Coniacian-Santonian transition.

\section{GEOLOGICAL SETTING AND STRATIGRAPHY}

The studied sections of Lipnik-Kije and Dubovcy (Text-fig. 1) are located on oposite sides of the main Mesozoic structural feature known as the Mid-Polish Anticlinorium (Text-fig. 1). It is usually interpreted as the inverted part of a former Danish-Polish Trough (e.g. Pożaryski et al. 1979). The time and rate of inversion has been a matter of massive discussion with arguments for the start of the inversion in the Maastrichtian on the one hand or in the Coniacian/Santonian times, during Subhercynian tectonic movements, on the other hand. Interestingly, Rogala (1909), Nowak (1907, 1908), and Samsonowicz (1925) amongst other researchers, mainly before World War II, interpreted the SE part of the Danish-Polish Trough as an emerged area (Łysogóry-Dobruga Land). In such interpretation this land would have been located between Lipnik-Kije and Dubovcy.

\section{Lipnik-Kije section}

The Lipnik-Kije composite section [50³6’52.60'N 20³4’30.95' E], first studied by Walaszczyk (1992), has recently been investigated in detail and proposed as a standard reference section for the Santonian of Poland (Remin 2004, 2010). The later studies resulted in the discovery of an exceptionally rich fossil assemblage, which allowed the establishment of a precise inoceramid bivalve (in prep.) and ammonite (Remin 2010) zonation.

The studied section is situated within the SW Mesozoic margin of the Holy Cross Mountains (Text-fig. 1), to the south west of the Mid-Polish Anticlinorium (Textfig. 1), which represents an inverted part of the DanishPolish Trough (e.g. Pożaryski 1964, 1997; Pożaryski et al. 1979). The Lipnik-Kije area constitutes the northeastern part of the Miechów Synclinorium and represents an area with a continuous, expanded and stratigraphically complete 150 meter-thick Santonian succession (Remin 2004, 2010). The studied interval covers the Middle-Upper Coniacian to Lower Santonian and is composed of pale grey, hard and thick-bedded siliceous limestones (referred to locally as 'opokas'). The lithology changes markedly in the middle part of the Middle Santonian from pure, hard and indurated opokas to soft, grey marls with ocasional plant debris and sandy intercalation (for details see Remin 2004).

Inoceramid bivalves are relatively common throughout the succession. They are represented by frequent Volviceramus involutus (Sowerby, 1828), followed by

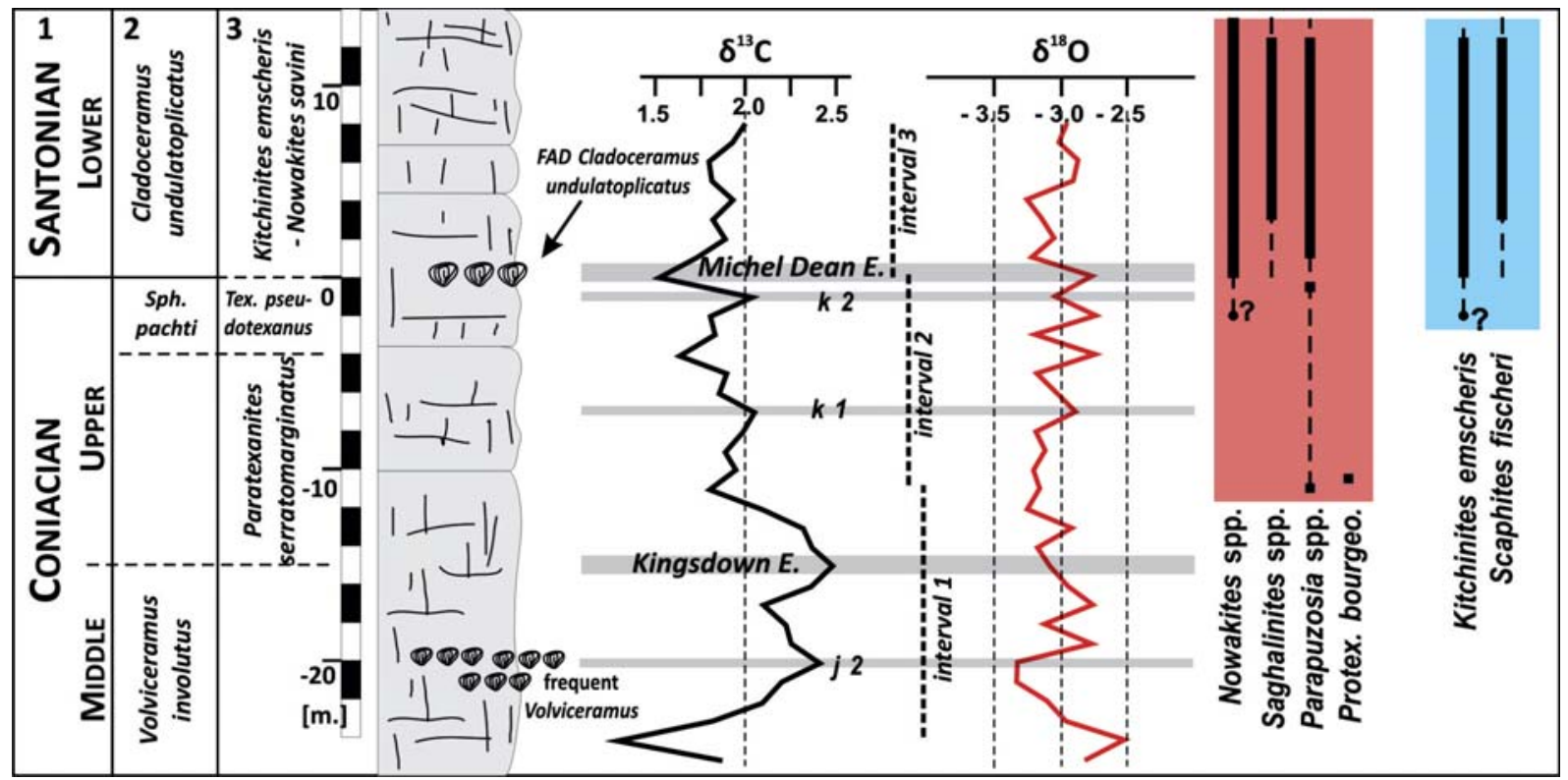

Text-fig. 2. Coniacian-Santonian at the Lipnik-Kije section; the events are identified using the faunas and related to the UK carbon isotope curve of Jarvis et al. (2006); the Middle-Upper Coniacian boundary proved indirectly on ammonites is related to the Kingsdown Event; FAD of Cladoceramus undulatoplicatus marks the Coniacian-Santonian boundary and is associated by the Michel Dean Event. See text for further discussion of carbon stable isotope events. Stratigraphic distribution of selected Tethyan (red) and Boreal (blue) ammonites 


\section{ZBYSZEK REMIN ET AL}

Sphenoceramus pachti (Arkhangelsky, 1912) (Text-fig. 2). The latter taxon appear $4 \mathrm{~m}$ below the ConiacianSantonian boundary, and defines the base of the eponymous zone of latest Coniacian age. An Upper Coniacian Magadiceramus subquadratus (Schlüter, 1887) Zone, preceding the Sph. pachti Zone, has not been recognized in the Lipnik-Kije section (see Remin 2004, 2010). However, it is known from nearby areas (Walaszczyk 1992). The base of the Santonian Stage is defined by the FAD of the inoceramid bivalve species $C$. undulatoplicatus (Text-fig. 2); its last occurance marks the base of the Middle Santonian, although this boundary cannot be drawn directly in the studied section (Remin 2010).

\section{Dubovcy section}

In terms of paleogeography, the Dubovcy section is located to the northeast of of the former Danish-Polish Trough, and lies on the SW margin of the East European Platform (Text-fig. 1). Upper Cretaceous deposits are well exposed in western Ukraine encompassing the interval from the Cenomanian through Maastrichtian (e.g. Rogala 1908-1911; Nowak 1907-1914; Samsonowicz 1925; Kokoszyńska 1931; Pasternak 1959; Ivannikov et al. 1987; Pasternak et al. 1968; Pasternak et al. 1987; Gavrilishin et al. 1991; Vashchenko et al. 2007).

The studied section is located about $100 \mathrm{~km} \mathrm{SE}$ of Lwów, close to the city of Halicz, about $1 \mathrm{~km}$ east of the village of Dubovce (Text-fig. 1) [49 $06^{\prime} 55.08^{\prime \prime} \mathrm{N}$; $\left.24^{\circ} 47^{\prime} 46.90^{\prime \prime} \mathrm{E}\right]$. The section, together with list of fauna, has been described by Pasternak et al. (1968, 1987) and Gavrilishin et al. (1991). A detailed study of foraminifera across the Coniacian-Santonian boundary was provided by Dubicka et al. (2014). Dubovcy, although one of the most important Upper Cretaceous sections in western Ukraine, has not been investigated previously using stable carbon and oxygen isotopes. The present study reports data for the Coniacian-Santonian transition; the whole Upper Cretaceous succession is under study and results will be published separately.

The Dubovcy consists of two sections exposed in separate quarries - Dubovcy I and Dubovcy II; with the latter encompassing the Coniacian-Santonian transition. The Dubovcy II section starts with a very characteristic bioclastic limestone unit which is composed almost exclusively of inoceramid bivalve debris (compare Rogala 1909). This distinctive unit is overlain by yellowish, thinbedded siliceous limestones. The macrofauna is relatively common, including frequent $V$. involutus which is also present in the underlying inoceramid-rich beds. A few meters higher up in the succession, M. subquadratus was noted; this species defines the Upper Coniacian (Text-fig. 3 ). Higher up, the thin-bedded siliceous limestones pass relatively rapidly (within a 3 -meter-thick interval), into a more and more marly succession. This gradual change in lithology predates the base of the Santonian (Text-fig. 3), marked by the FAD of C. undulatoplicatus. The Lower Santonian inoceramids come, mainly, from distinct inoceramid-rich horizons (Text-fig. 3). The base of the

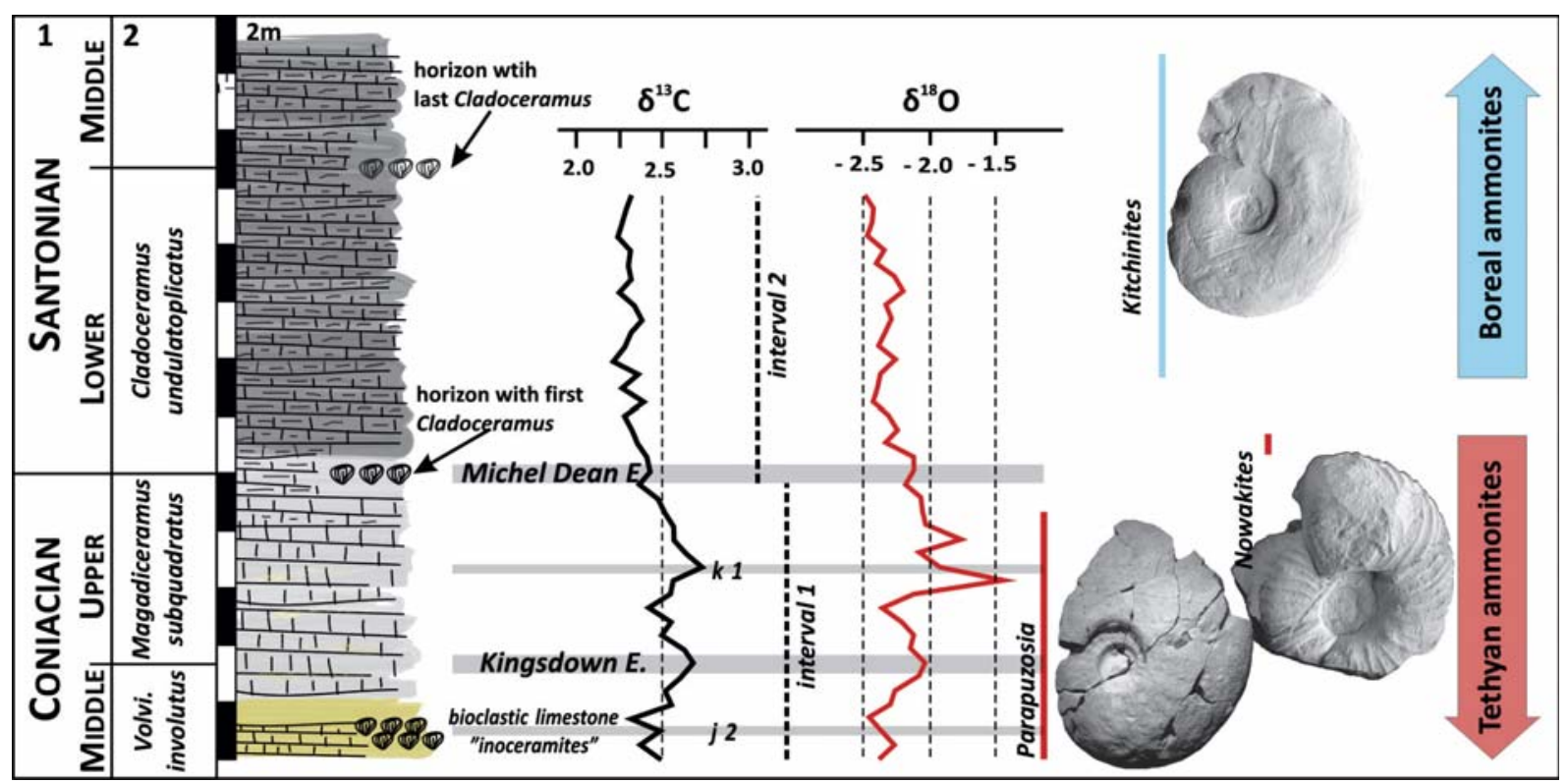

Text-fig. 3. Coniacian-Santonian in the Dubovcy II section; the events are identified using the faunas and related to the UK carbon isotope curve of Jarvis et al. (2006); the Middle-Upper Coniacian boundary marked by the FO of Magadiceramus subqudratus is related to the Kingsdown Event; FAD of Cladoceramus undulatoplicatus marks the Coniacian-Santonian boundary, and is associated by the Michel Dean Event. See text for further discussion of carbon stable isotope events.

Stratigraphic distribution of selected Tethyan (red) and Boreal (blue) ammonites 
Middle Santonian is marked by a horizon where last $C$. undulatoplicatus was noted (Text-fig. 3).

\section{MATERIAL AND METHODS}

\section{Ammonites}

The ammonites from the Middle-Upper Coniacian through to the basal Campanian of the Lipnik-Kije section were fully described in Remin (2010) to which a reader is referred for a full list of species. The ammonites of the Dubovcy section are new collections and came from the interval encompassing the MiddleUpper Coniacian to basal Campanian. Detailed paleontological description will be provided elsewhere.

\section{Geochemistry - stable carbon and oxygen isotopes}

Samples for carbon and oxygen stable isotope analyses were obtained from slabs of rocks. In the Lipnik-Kije section, samples were collected at metre intervals, whereas in the Dubovcy II section they were collected half-meter intervals. Carbon and oxygen stable isotope data were obtained automatically using a Thermo KIEL IV Carbonate Device connected on-line wtih massspectrometer Finnigan Delta Plus - Dual Inlet system (Light Stable Isotopes Laboratory of the Institute of Geological Sciences and Institute of Palaeobiology, Polish Academy of Sciences, Warszawa). Samples containing at least $20 \mu \mathrm{g}$ of carbonate were reacted with orthophosphoric acid at $70^{\circ} \mathrm{C}$; one international standard [NBS19] was analysed per 10 samples. All isotopic data are reported in per mil with reference to the VPDB international standard [NBS19]. Precision $(1 \sigma)$ : for carbon $\delta^{13} \mathrm{C}+/-0.03 \%$; for oxygen $\delta^{18} \mathrm{O}+/-0,07 \%$.

\section{Diagenetic screening}

Selected samples from the Lipnik-Kije and Dubovcy sections, were examined by means of cathodoluminescence (thin sections) and SEM (rock chips), to investigate the likely degree of diagenesis and possible impact on the $\mathrm{C}$ and $\mathrm{O}$ isotope compositions. Polished thin sections were examined and photographed on a CITL/ Nikon cathodoluminescence photomicroscope (Central Teaching Laboratory, University of Liverpool) with typical operating conditions for carbonate luminescence (vacuum: $0.06 \mathrm{mbar}$, accelerating voltage: $12 \mathrm{kV}$ current: $400 \mu \mathrm{A}$ ). Secondary electron (SE) SEM images were obtained from carbon-coated rock chips on a Phillips XL30 scanning electron microscope (University of Liverpool) typically operating with a $20 \mathrm{kV}$ electron beam.

\section{RESULTS}

\section{Ammonites}

Lipnik-Kije section

The Middle-Upper Coniacian of the Lipnik-Kije section is characterized by forms typical of the Tethyan Realm. Representative genera include Parapuzosia Nowak 1913, Protexanites Matsumoto 1955 and Nowakites Spath, 1922, as well as more widely distributed acanthoceratids of the genus Texanites Spath 1932. The Lower Santonian is characterized by two different co-occurring ammonite assemblages, constituting a Kitchinites emscheris - Nowakites savini assemblage Zone (Remin 2010), which probably extends at least up to the middle part of the Middle Santonian. The Novakites savini assemblage consists of Tethyan elements characterized by different species of the genera Nowakites, Parapuzosia and Sagalinithes Wright and Matsumoto, 1954, while the Kitchinites emscheris assemblage is characterized by typical Boreal forms, i.e. K. emscheris Lommerzheim, 1995 and Scaphites fisheri (Riedel, 1931).

\section{Dubovcy section}

The Middle and Upper Coniacian of the Dubovcy section is characterized by relatively frequent ammonites, consisting however, exclusively of representatives of Parapuzosia daubreei (de Grossouvre, 1894). The lowermost Santonian is additionally characterized by single specimens of Nowakites savini (de Grossouvre, 1894) and Texanites sp., thus still showing influences of Tethyan water masses. Higher up in the section, Tethyan ammonites disappear and are replaced by typical Boreal desmoceratids of the Kitchinites group, recorded from the middle part of the Lower Santonian. Higher up in the succession, within the dark marls of Early and Middle Santonian age, macrofauna becomes extremely rare, and ammonites disappear completely. Other cephalopods are represented by cold water belemnites of the genus Gonioteuthis (Bayle, 1878).

\section{Stable Isotope Geochemistry}

\section{Lipnik-Kije section}

Carbon: The stable carbon isotope curve shows three discrete intervals (Text-fig. 2) within the ConiancianSantonian transition: 1) a double spined positive excursion, 2) a falling limb, and 3) a slow rise in values 


\section{ZBYSZEK REMIN ET AL}

(intervals 1-3 in Text-fig. 2). The Middle Coniacian $\delta^{13} \mathrm{C}$ values show a $-0.6 \%$ drop from 1.9 to $1.3 \%$ o $\delta^{13} \mathrm{C}$. The carbon-isotope values increase and display a $+1.1 \%$ distinct positive excursion reaching double peaks with values around $2.4 \%$ and $2.5 \%$ respectively, separated by a $-0.3 \%$ negative trough (interval 1). The second peak is an inflection point followed by a long-term fluctuating fall to values as low as $1.5 \%$ (interval 2). Towards the end of this long-term fall, the Coniacian-Santonian boundary is marked by FO of $C$. undulatoplicatus. Higher up, through the Lower Santonian the $\delta^{13} \mathrm{C}$ values increase by around $+0.5 \%$ (interval 3).

Oxygen: The $\delta^{18} \mathrm{O}$ values more or less oscillate around $-3.1 \%$ in the whole studied interval. The oscillations in the $\delta^{18} \mathrm{O}$ values do not exceed $0.5 \%$ o (Text-fig. 2).

\section{Dubovce section}

Carbon: The stable carbon isotope curve shows two main intervals (Text-fig. 3) within the ConiancianSantonian transition. The middle Coniacian $\delta^{13} \mathrm{C}$ values are around $2.5 \%$, followed by a minor increase in values, reaching a double peak with maximal values of $2.7 \%$, separated by a $-0.3 \%$ negative trough (interval 1). The first maximum coincides with the FAD of $M$. subquadratus that marks the base of the Upper Coniacian. The second peak marks an inflection point towards a long-term decrease with a weakly fluctuating fall to $\delta^{13} \mathrm{C}$ values as low as $2.2 \%$. Within this fall the Coniacian-Santonian boundary is marked by FAD of C. undulatoplicatus. Higher up, in the Lower Santonian, the $\delta^{13} \mathrm{C}$ values are characterized by values oscillating around $+2.3 \%$ (interval 2 ).
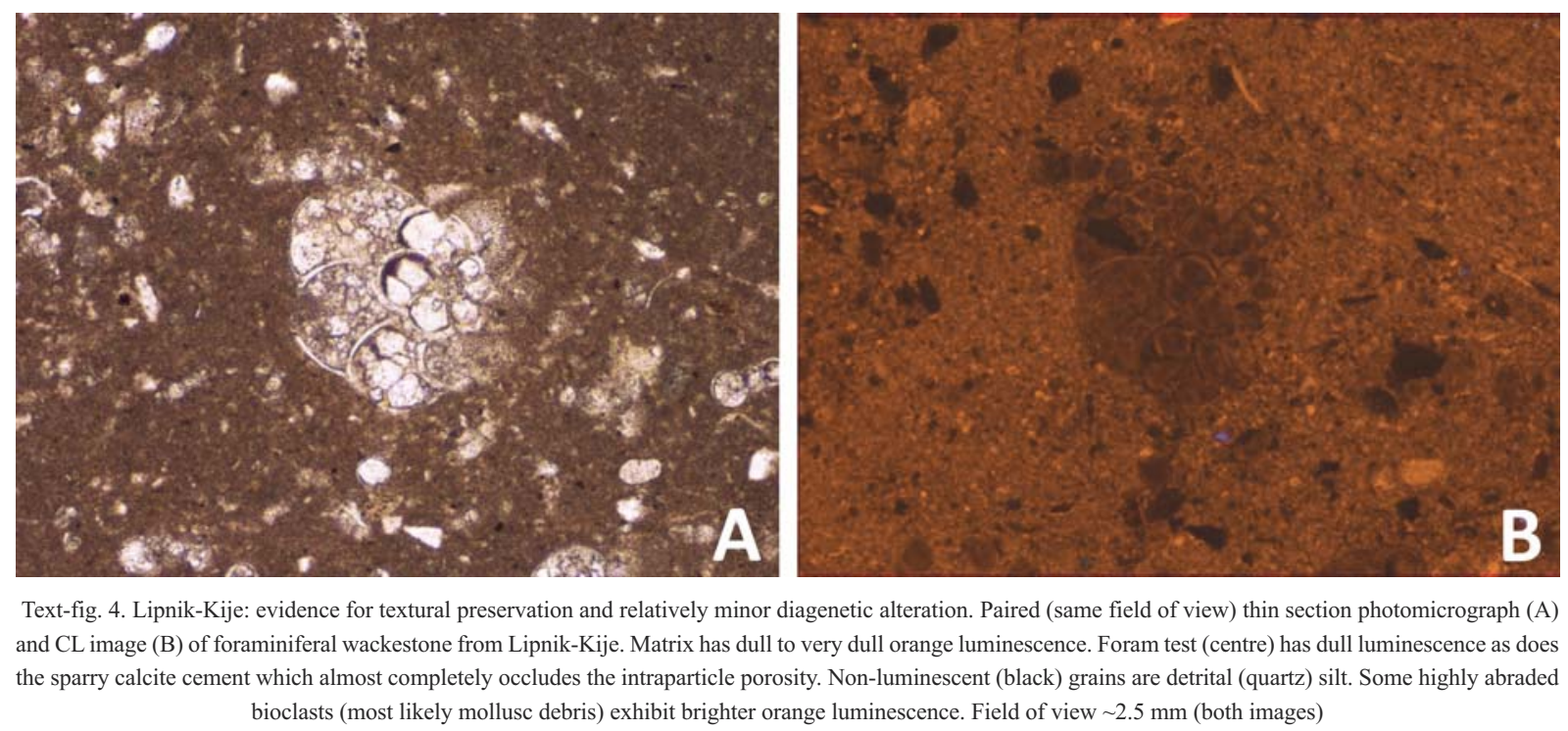

Text-fig. 4. Lipnik-Kije: evidence for textural preservation and relatively minor diagenetic alteration. Paired (same field of view) thin section photomicrograph (A) and CL image (B) of foraminiferal wackestone from Lipnik-Kije. Matrix has dull to very dull orange luminescence. Foram test (centre) has dull luminescence as does the sparry calcite cement which almost completely occludes the intraparticle porosity. Non-luminescent (black) grains are detrital (quartz) silt. Some highly abraded bioclasts (most likely mollusc debris) exhibit brighter orange luminescence. Field of view $\sim 2.5 \mathrm{~mm}$ (both images)
Oxygen: The $\delta^{18} \mathrm{O}$ values show two different characteristics (Text-fig. 3). The Middle and Upper Coniacian as well as the lowermost Santonian display a long-term positive $+1.1 \%$ increase in $\delta^{18} \mathrm{O}$ values reaching a maximum of $-1.5 \%$, whereas the rest of the studied Lower Santonian records a long-term fall towards $-2.5 \%$ o $\delta^{18} \mathrm{O}$.

\section{Petrography and diagenesis}

\section{Lipnik-Kije section}

The studied samples are fine-grained foraminiferal bioclastic wackestones to packstones. Some display mottled fabrics indicative of (micro-) bioturbation. The matrix contains a few dispersed quartz and feldspar grains. Cements are rarely seen in thin section and many foraminifera tests remain as open pores. In terms of CL response, the micrite generally has very dull orange luminescence but the mottled samples show marked variation in luminescence with dull cores and brighter margins in the mottled patches (Text-fig. 4). Foraminiferal calcite is generally very dull or nonluminescent (Text-fig. 4). Molluscan debris is relatively rare but shell fragments can show dull to bright orange luminescence. The secondary electron SEM images demonstrate that the matrix is dominated by coccolith debris. Microscopic calcite cements partially occlude matrix porosity.

\section{Dubovce section}

The limestones from the Dubovcy section are dominantly micritic wackestones with local foraminiferal packstones. There is some evidence of grain to grain 

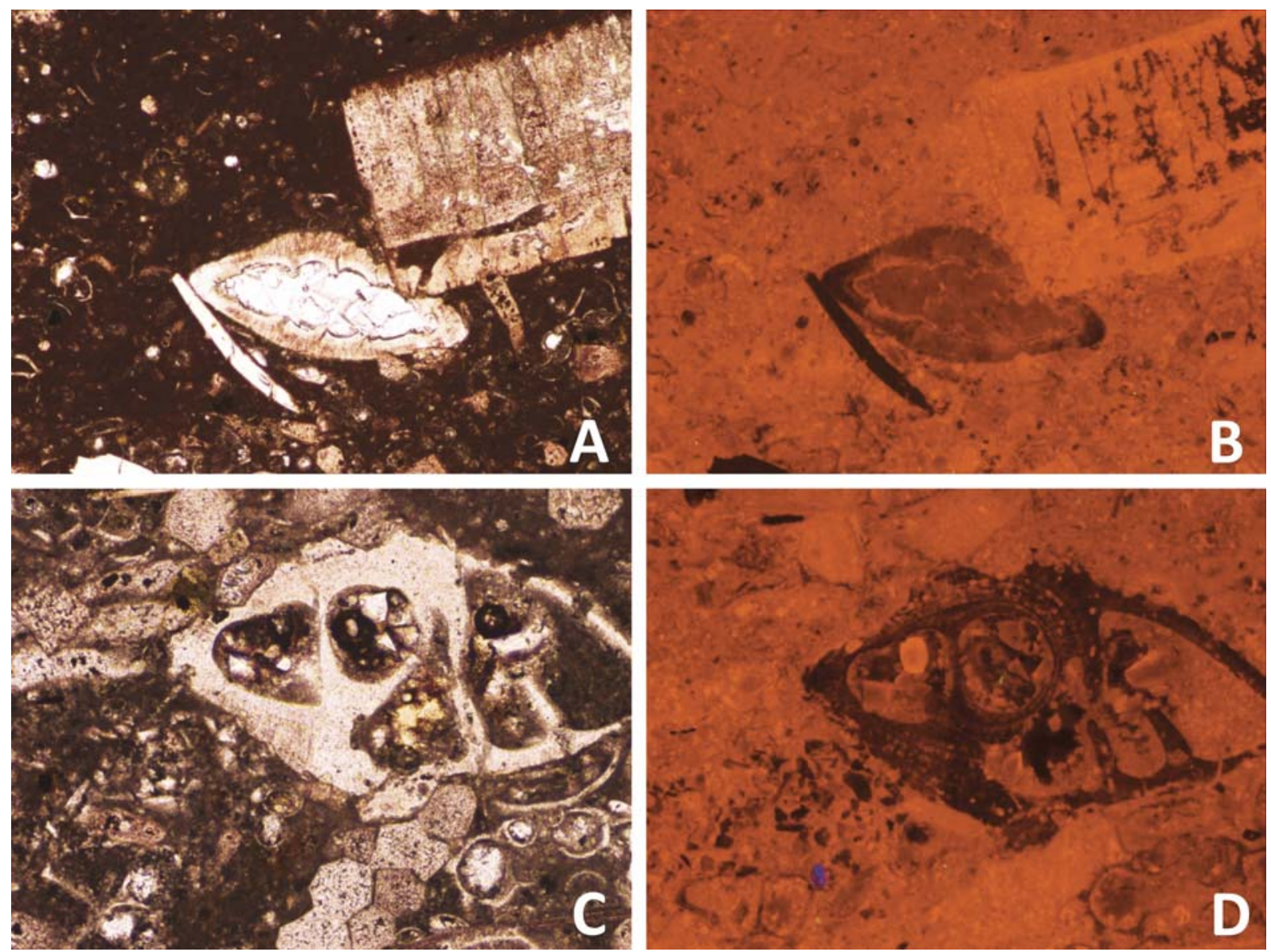

Text-fig. 5. Paired thin-section, A-B and C-D photomicrographs (transmitted light photomicrograph; left) and CL images (right) of foraminiferal wackestone and packstone from Dubovcy. Micrite matrix has relatively bright luminescence. Most bioclasts and foraminiferal tests exhibit dull- or non-luminescence while columnar/prismatic (inoceramid) calcite exhibits relatively bright luminescence. Dull luminescent sparry calcite cements fill or partially fill intraparticle pores. Areas of non-luminescence in prismatic shell in B are due to partial silicification. Field of view $\sim 2.5 \mathrm{~mm}$ for A and B and $\sim 1.25 \mathrm{~mm}$ for C and D

compaction and pressure dissolution. The matrix contains a few dispersed quartz and feldspar grains. In terms of CL, the matrix displays a uniform dull to bright orange luminescence (Text-fig. 5). Foraminiferal bioclasts are non luminescent as are both the detrital quartz and replacive quartz (at $12 \mathrm{kV}$ beam excitation). K-feldspar detrital grains display a blue luminescence (Text-fig. 5). Some prismatic molluscan bioclasts display pervasive orange luminescence (Text-fig. 5). The centres of these grains appear to have been preferentially silicified. In thin section, cements fill or partially fill intragranular pores within foraminiferal chambers. These cements are generally dull orange or non-luminescent (Text-fig. 5). The secondary electron SEM images (Fig. 6) demonstrate that the matrix is dominantly composed of coccoliths and coccolith fragments with a more or less pervasive micro-spar calcite cement. Less cemented areas retain a relatively high porosity (Text-fig. 6).

\section{DISCUSSION}

\section{Likelihood of preservation of stratigraphic isotopic signals}

The petrological data (above) clearly indicate that the sediments from both Lipnik-Kije and Dubovcy have been affected by diagenetc alteration. Cements are visible in thin-sections and under the SEM. Pristine, unaltered marine carbonate would likely be almost non-luminescent so the variable cathodoluminescence of the samples and the individual bioclasts also indicates variable degrees of alteration. Interestingly, however, the bulk-rock isotope values from both of the studied sections are very similar to those from other European sections where the diagenesis has not been explicitly studied (Text-fig. 7).

A detailed account of the diagenesis is beyond the scope of this paper but it is appropriate to comment on 

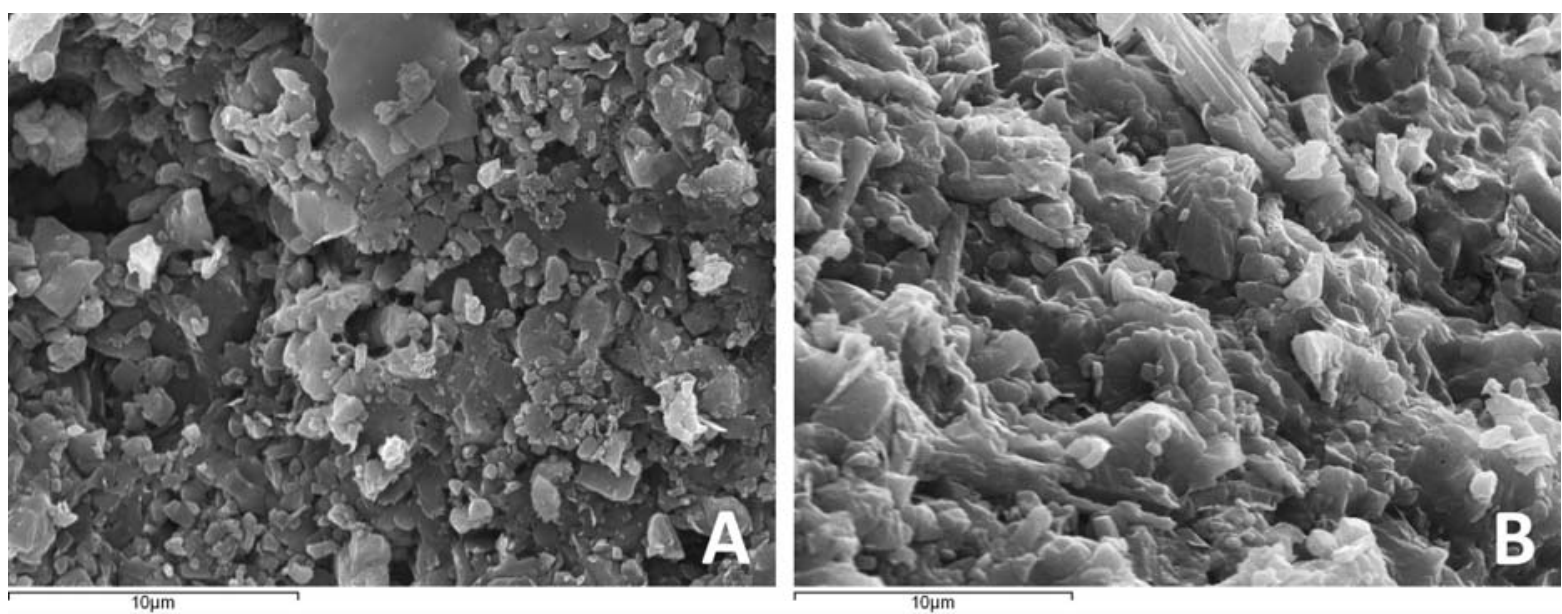

Text-fig. 6. Dubovcy: Secondary electron SEM photomicrographs of porous (A) and cemented (B) limestones. Bioclasts (platy shell fragments with entire and fragmented coccoliths) are set in a microsparry calcite cement which partially (A) or almost totally (B) fills primary interparticle porosity; scale bars, $10 \mu \mathrm{m}$, below photomicrographs

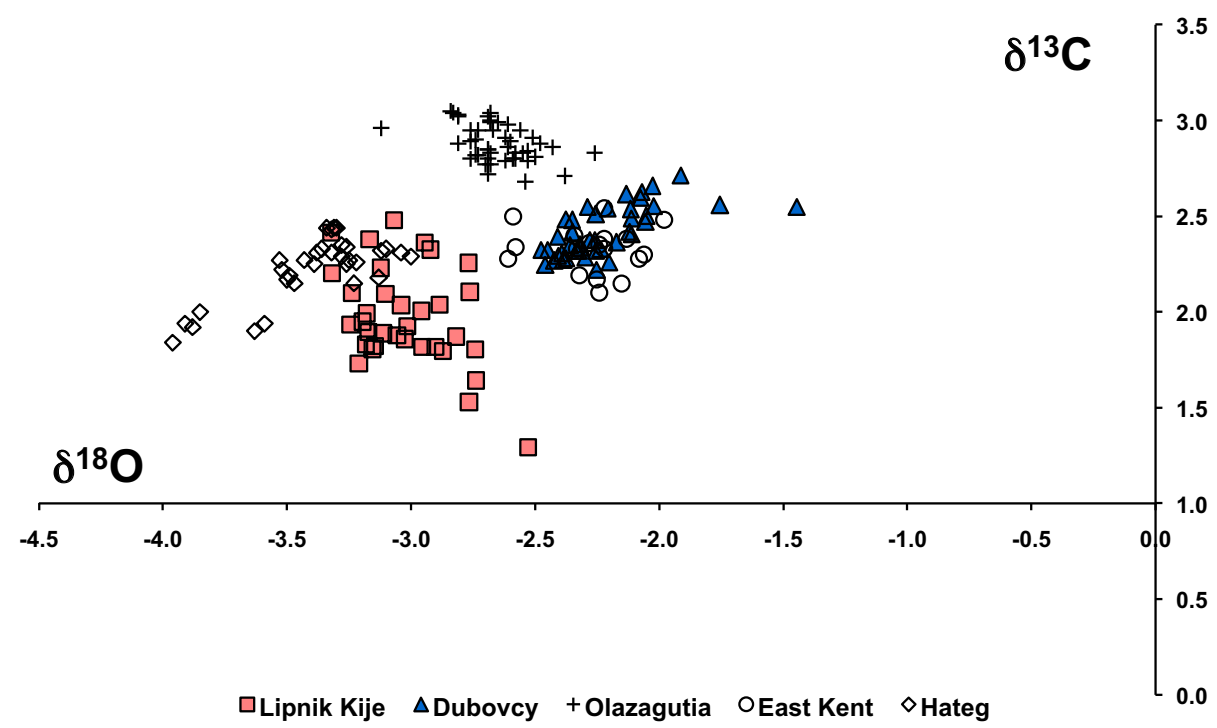

Text-fig. 7. Stable isotope data from Lipnik-Kije and Dubovcy (this study) compared to data from the equivalent stratigraphic intervals in the other sections in Europe. Notably the oxygen isotopic values from Lipnik-Kije, Poland overlap with those from Fizesti (Hateg area, Romania) while the samples from Ukraine are similar to those from East Kent. Samples from Olazagutia (N Spain) have intermediate oxygen values but higher carbon values than the other sections

the possible consequences of diagenesis for the interpretation of stratigraphic patterns and paleoceanographic conditions. In general, diagenetic alteration of relatively deep water 'chalks' does not lead to the major shifts in isotopic composition that are found in shallow water limestones and organic-rich sediments (Hudson 1977). Cementation and recrystallisation at or near the sea-floor can lead to preservation of isotopic values that reflect the marine environment. Burial diagenesis commonly leads to lower oxygen values, with introduction of cements at elevated burial temperatures and somewhat lower carbon values (Hudson 1977; Marshall 1992). Different de- grees of cementation between lithologies, however, can lead to stratigraphic fluctuations which can be confused with changes in paleotemperatures (Mitchell et al. 1997).

There is no evidence that the isotopic compositions of the samples from Lipnik-Kije or Dubovcy have been unduly affected by diagenesis. The isotopic values as displayed on the cross plot diagram (Text-fig. 7) are clumped and typical of normal marine limestones. In the absence of significant shifts in composition (or covariance with oxygen values), the carbon isotope values largely are likely to reflect primary paleooceanographic 
conditions. The observed diagenesis has most likely lead to a pervasive decrease in oxygen isotope values. So, whilst the oxygen values are very unlikely to be absolutely pristine and it would be unwise to attribute small changes in values to absolute temperature change, the coherence of data on the cross plots encourages us to suggest that the patterns may reflect primary differences between Lipnik-Kije and Dubovcy, and, with caution, with the other European successions.

\section{Correlation}

Since the pioneering paper of Scholle and Arthur (1980) the pattern of $\delta^{13} \mathrm{C}$ values for the Upper Cretaceous has been used as a chemostratigraphic tool for correlation between distant sedimentary sections. Its usefulness for global correlation has been proved by different authors for different intervals (e.g. Schlanger et al. 1987; Arthur et al. 1990; Jenkyns et al. 1994; Voigt and Hilbrecht 1997; Voigt 2000; Voigt and Wiese 2000; Gale et al. 2005, 2007; Lamolda and Paul 2007; for a complete review see Jarvis et al. 2006). Jarvis et al. (2006) provided detailed carbon stable isotope data for the Cenomanian - Campanian plotted against the lithoand biostratigraphic logs of the Chalk succession in England. Positive and negative excursions of $\delta^{13} \mathrm{C}$ and inflection points were used to define 72 isotope events. As they noted, their reference curve is remarkably similar in shape to published, supposedly eustatic, sealevel curves with increasing $\delta^{13} \mathrm{C}$ values accompanying sea-level rise and transgression, and falling $\delta^{13} \mathrm{C}$ values characterizing sea-level fall and regression. Although an increasing number of Coniacian-Santonian (mid-Upper Cretaceous) sedimentary sections around the world have been investigated by means of stable isotope geochemistry (Coplen and Schlanger 1973; Arthur et al. 1985; Jenkyns et al. 1994; Huber et al. 1995; Gruszczyński et al. 2002; Zapata et al. 2003; Leckie et al. 2005; Jacobs et al. 2005; Li et al. 2006; Jarvis et al. 2006; Lamolda and Paul 2007; Gale et al. 2007), detailed correlation of stable isotope curves for the Coniacian-Santonian boundary interval, is less clear-cut than for other Upper Cretaceous intervals (Jarvis et al. 2006).

In general, the Middle to Upper Coniacian and basal Santonian may be recognized by a combination of $\delta^{13} \mathrm{C}$ events and their relationship to specific palaeontological markers (so-called 'bioevents'; Lamolda and Paul 2007). In the Chalk succession of England, the carbon curve continues a long-term rise through the Middle Coniacian (Text-fig. 8). Values reach a maximum around the Middle-Upper Coniacian boundary and represent an inflection point towards long-term fall through the Up- per Coniacian into the Lower Santonian. This maximum represents the Kingsdown Isotope Event of Jarvis et al. (2006). The base of the Upper Coniacian is defined by the FAD of $M$. subquadratus which is recorded in the Dubovcy section; the base of Upper Coniacian in the Lipnik-Kije section is indirectly proved by the occurence of selected ammonites (compare Remin 2010). This biostratigraphic boundary therefore equates with the maximum represented by Kingsdown Isotope Event (Text-figs 2 and 3).

In the case of the Coniacian-Santonian boundary, the carbon stable isotope compositions obtained from the Lipnik-Kije and Dubovcy sections is a little more problematic, however, the base of the Santonian in both sections is defined biostratigraphically by FAD of the inoceramid bivalve C. undulatoplicatus. This datum is located close to the small negative peak on a long-term weakly fluctuating fall of $\delta^{13} \mathrm{C}$ (interval 2 in Text-figs 2 and 3 ). It has been recognized in several European sections as the Michel Dean Isotope Event of Jarvis et al. (2006) (Text-fig. 8).

\section{Kingsdown Isotope Event - Middle-Upper Coniacian boundary}

In the UK Chalk succession, the Kingsdown Event represent a maximum around the Middle-Upper Coniacian boundary and is an inflection point after a Middle Coniacian long-term rise. The Kingsdown peak is situated $5 \mathrm{~m}$ above the East Cliff Semitabular Flint, a distinctive marker bed containing abundant platyceramids and volviceramids (Jarvis et al. 2006). The latter marker bed occurs ca. $5 \mathrm{~m}$ above the less prominent j2 event of Jarvis et al. (2006).

In the Lipnik-Kije and Dubovcy sections, within intervals 1 (compare Text-figs 2 and 3), the Kingsdown Isotope Event can easily be traced as the pattern mirrors in general the trend observed for the UK Chalk succession. In the Lipnik-Kije section, the Middle-Upper Coniacian boundary, although not proved by inoceramids, i.e. M. subquadratus, can be drawn on the basis of ammonites and is represented by the $\delta^{13} \mathrm{C}$ maximum of $2.5 \%$, which is correlated here with the Kingsdown Event (Text-figs 2 and 8). In the Dubovcy section, the Kingsdown Event is even better expressed than in Lipnik-Kije and can be directly linked with Middle-Upper Coniacian boundary marked by the FAD of $M$. subquadratus, represented by a $\delta^{13} \mathrm{C}$ peak of $2.7 \%$ (Textfigs 3 and 8). Surprisingly, and similarly to the UK Chalk succession, the Kingsdown Event lies approximately $5 \mathrm{~m}$ above beds containing abundant volviceramids in the case of Lipnik-Kije, and 2-3 meters above a characteristic bioclastic limestone composed almost 


\section{ZBYSZEK REMIN ET AL}

exclusively of volviceramid debris in Dubovcy. Those marker beds with abundant Volviceramus are tentatively correlated with the East Cliff Semitabular Flint and are broadly related to the $j 2$ Event of Jarvis et al. (2006).

\section{Michel Dean Isotope Event - Coniacian-Santonian boundary}

Above the Kingsdown Event, $\delta^{13} \mathrm{C}$ values continue a long-term fall within the Upper Coniacian into the Lower Santonian (Text-fig. 8). The Coniacian-Santonian, defined by the FAD of Cladoceramus undulatoplicatus, consistently occurs around a negative peak immediately followed by a positive exursion of different magnitude in the studied and reference sections (compare Text-figs 2, 3 and 8), constituting the Michel Dean Isotope Event (Jarvis et al. 2006). Two less consistently developed positive excursions within the Upper Coniacian are informally numbered events $k 1$ and $k 2$ (compare Jarvis et al. 2006).

In the studied sections of Lipnik-Kije and Dubovcy, the FAD of C. undulatoplicatus correlates with the general position of the Michel Dean Isotope Event on a long term fall (compare intervals $2 / 3$ in Text-fig. 2). However, in detail the pattern of a negative peak followed by immediate increase in $\delta^{13} \mathrm{C}$ is variously expressed in particular sections (Text-figs 2, 3 and 8). In respect to the magnitude of changes in $\delta^{13} \mathrm{C}$ record, the differences in pattern of the Michel Dean Isotope Event in the studied sections are most likely within the noise in the signal produced by differences in content of bioclasts and di- agenesis (especially in the case of Dubovcy). In LipnikKije, two positive exursions between the Kingsdown and Michel Dean Events most likely equate to the informal events $k 1$ and $k 2$ (compare interval 2 in Text-fig. 2) as recognized in the UK Chalk (Jarvis et al. 2006). In Dubovcy only one positive exursion occurs within the Upper Coniacian and is provisionally interpreted here to represent event $k 1$ (compare interval 1 in Text-fig. 3). The lack of the $k 2$ informal event at Dubovcy can be result of different factors, including diagenetic overprint or biased sampling. Speculating, it may also be due to the presence of a small stratigraphic gap, which is however, undetectable within the current biostratigraphic resolution.

At the GSSP for the base of the Santonian Stage at Olazagutia section, Navarra, Spain, the FAD of C. undulatoplicatus occurs just above a negative peak and correlates with the beginning of an increase in $\delta^{13} \mathrm{C}$ values (Lamolda and Paul 2007; Text-fig. 8). In the case of the Ten Mile Creek section (Lancaster, Dallas County, Texas), a former GSSP candidate section studied by Gale et al. (2007), the FO of C. undulatoplicatus corresponds to a minor trend of decreasing $\delta^{13} \mathrm{C}$ values between the $k 2$ and Michel Dean events of Jarvis et al. (2006), but very close to the latter event.

\section{Paleotemperature patterns}

Although less reliable for correlation than carbon curves, we used the oxygen isotopes in combination with paleontological evidence as potential indicators of paleotemperature changes. We realize that to interpret

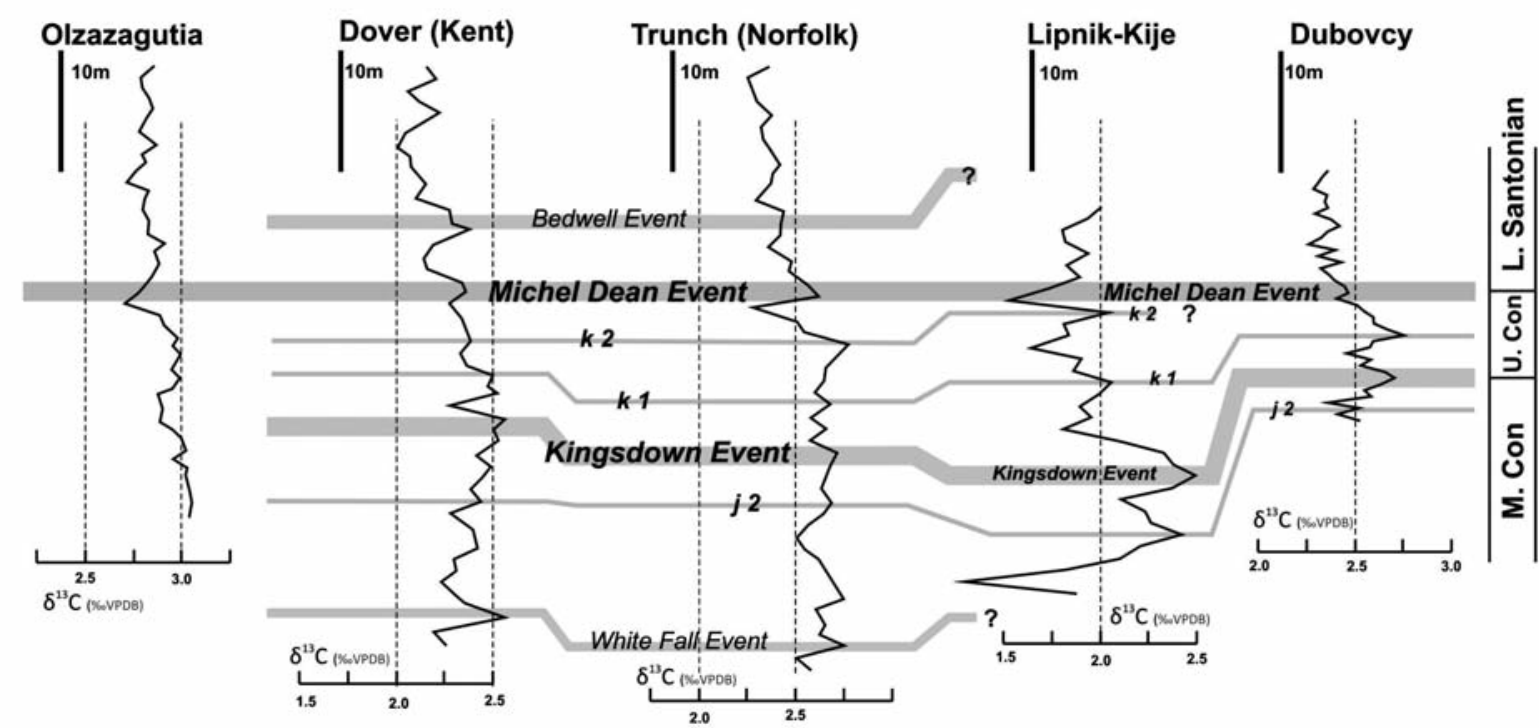

Text-fig. 8. Correlation of the Coniacian-Santonian $\delta^{13} \mathrm{C}$ curves; Olazagutia (Lamolda and Paul, 2007); East Kent (Jenkyns et al. 1994); Dover and Trunch (Jarvis et al. 2006); Lipnik-Kije and Dubovcy (this paper). Note that vertical and horizontal scales for all curves have the same scale 
PALEO-CIRCULATION AND AMMONITES AT THE CONIACIAN-SANTONIAN TRANSITION IN CENTRAL EUROPE

the offset in bulk data $\delta^{18} \mathrm{O}$ curves between particular sections in terms of paleotemperatures can be questionable, although relative trends and the magnitude of differences in bulk-rock oxygen isotopes can be interpreted as gross climate signals (Stoll and Schrag 2000; Voigt and Wiese 2000). It is noteworthy that the inferred paleotemperature distribution across Europe presented here is in broad agreement with the faunal distribution which includes ammonites (this paper and Remin, 2010), foraminifera (Dubicka et al. 2014), and nannoplankton (Svabanicka 1995; Melinte and Lamolda 2002, 2007; Lamolda and Paul 2007; Melinte-Dobrinescu and Bojar 2010; Lamolda et al. 2014). We therefore assume that the pattern of $\delta^{18} \mathrm{O}$ differences in the studied sections reflects, at least in part, some original paleotemperature control.

On a regional scale, we compare the oxygen stable isotope records from East Kent, UK (Jenkyns et al. 1994), Olazagutia, Spain (Lamolda and Paul 2007), and Fizesti, Romania (Melinte-Dobrinescu and Bojar 2010), with the stable isotope record from around the Coniacian-Santonian interval of the Lipnik-Kije and Dubovce section (this paper). Apart from finding some similarities in the course of fluctuating $\delta^{18} \mathrm{O}$ values, we have noticed consistent differences in values which likely reflect difference in paleotemperature (Text-fig. 9). At Olazagutia, the average $\delta^{18} \mathrm{O}$ values $[\sim-2.6 \%$ are about $0.4-0.5 \%$ o lower for the Coniacian and $0.4 \%$ lower for the Santonian than those values in East Kent [ - 2.2\%o] (Text-figs 7 and 9), which may reflect orig- inally higher sea-water temperatures in the Spanish sea, a part of the tropical Atlantic, than in the English sea, a part of the Boreal Realm (Text-figs 9 and 10).

At Lipnik-Kije, the average $\delta^{18} \mathrm{O}$ values [ -3.1\% ] are $0.5 \%$ lower for both the Coniacian and Santonian than the average values at Olazagutia (Text-fig. 9). Therefore, surprisingly, the waters of the Polish sea, a part of the supposed Boreal Realm could have been even warmer than the waters of the Spanish sea, a part of the tropical Atlantic (Text-fig. 10). Looking at the paleogeographic position of the Lipnik-Kije area during the Coniacian-Santonian (Text-fig. 10), we might expect some interplay of warmer Tethyan and cooler Boreal water masses.

In the case of Dubovcy, distinct shift to less negative values could be observed in the latest Coniacian, followed by a gradual trend towards more negative values into the Early Santonian. This positive peak we interpret as a cooling phase represented by an increase of $\delta^{18} \mathrm{O}$ values of about $+0.9 \%$ from approximatelly $-2.3 \%$ o to $-1.4 \%$ in a relatively short time. In this interval, the $\delta^{18} \mathrm{O}$ values are consistently $1.5 \%$ higher than at LipnikKije. Such high values are largely surprising since paleogeographically the Dubovcy section is located in the mid point between Lipnik-Kije and Fizesti (Hateg) in Romania, for which the inferred paleotemperatures interpreted from bulk oxygen stable isotope are expected to be highest (Text-figs 9 and 10).

As mentioned above, the Fizesti section in Romania recorded low $\delta^{18} \mathrm{O}$ values. Around the Coniacian-San-

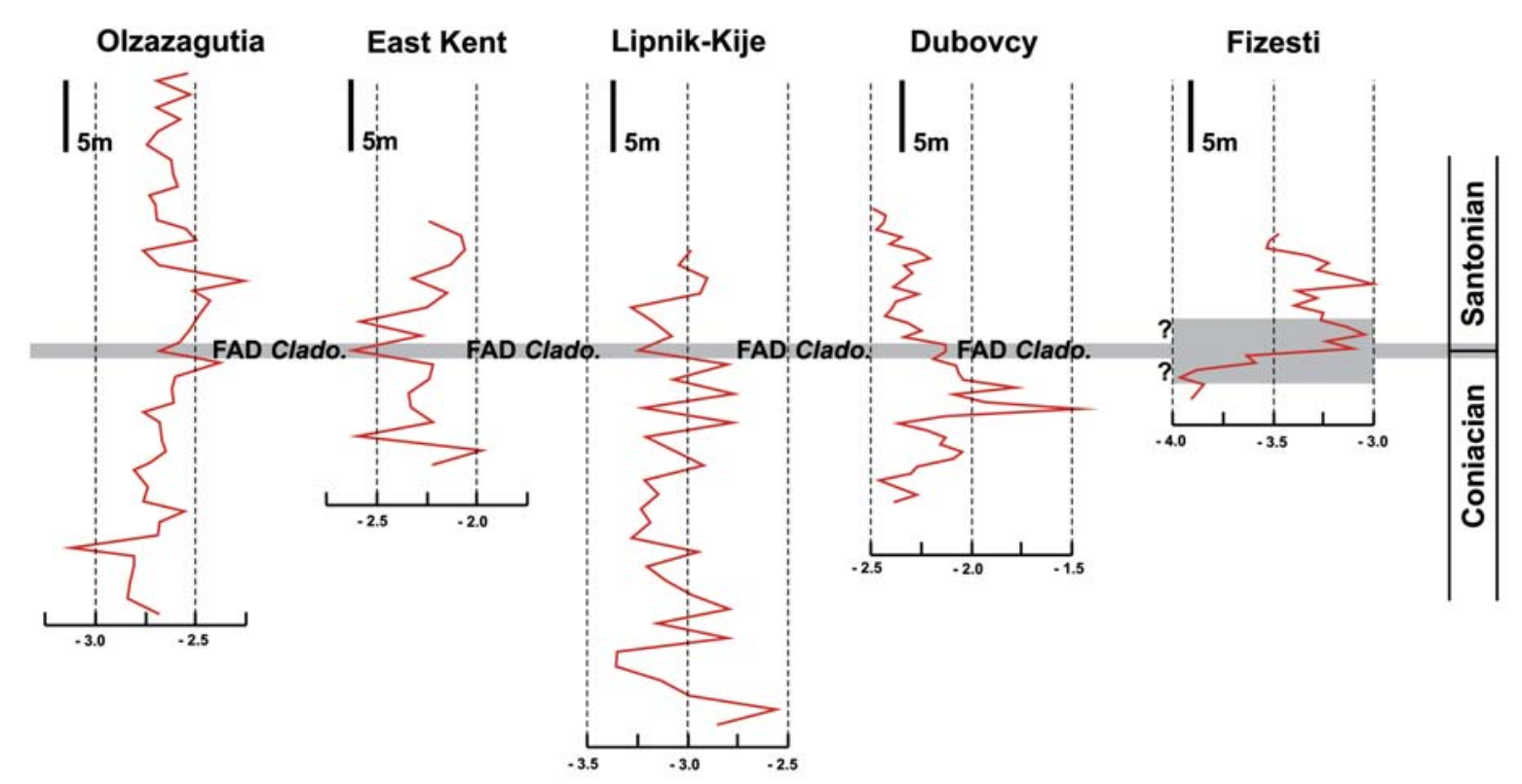

Text-fig. 9. Correlation and comparison of Coniacian-Santonian $\delta^{18} \mathrm{O}$ curves: Olazagutia, Spain (Lamolda and Paul 2007); East Kent, UK (Jenkyns et al. 1994); LipnikKije, Poland and Dubovcy, Ukraine (this paper); Fizesti, Hateg area, Romania (Melinte-Dobrinescu and Bojar 2010); note that the boundary interval is markedly wider at Fizesti since the $\mathrm{C}-\mathrm{S}$ boundary is not based on FAD of $C$. ndulatoplicatus, so is less well constrained. The vertical and horizontal scales for all curves are the same 


\section{ZBYSZEK REMIN ET AL.}

tonian boundary large and fast increase in $\delta^{18} \mathrm{O}$ values, from approximatelly $-4.0 \%$ to $-3.0 \%$, is observed with a magnitude of $+1.0 \%$ similar to that observed in the Dubovcy section in the latest Coniacian. The observed time-discrepancy in the shift to less negative values (Text-fig. 9) can be associated with the fact that the Conianian-Santonian boundary in Fizesti is based on the nannofossil Lucianorhabdus inflatus, which preceded the primary boundary marker, i.e. the FAD of $C$. undulatoplicatus (Melinte-Dobrinescu and Bojar 2007; Lamolda and Paul 2007; Lamolda et al. 2014). Despite this increase, the Fizesti section had the warmest climate on the basis of the bulk stable oxygen isotope values. In the absence of any diagenetic investigation of the sediments this inference must be treated with caution.

\section{Paleogeography and seawater paleo-circulation: discussion}

Both of the studied sections are located in close proximity to the axial part of the Mid-Polish Anticli- norium (Text-figs 1 and 10), interpreted as the inverted part of a former Danish-Polish Trough (e.g. Pożaryski et al. 1979). The time and rate of inversion has been a matter of considerable debate. Some authors argue for the start of the inversion in ConiacianSantonian times and other in the Maastrichtian (for the most recent disscussion compare Świdrowska et al. 2008; Krzywiec et al. 2009; Leszczyński 2012). Critical review of this topic has been provided recently by Walaszczyk and Remin (2015), who argue that none of those hypotheses explain everything. On the other hand, detailed spatial analyses of sedimentological data has been used by some of the authors to interpret the uplift of the eastern part of the Danish-Polish Trough in Coniacian-Santonian times during Subhercynian tectonic movements (Pasternak, 1959; Pasternak et al. 1987; Pożaryski 1964; Walaszczyk 1992; Krzywiec et al. 2009). Nowak (1907-1914), Rogala (1908-1911), Kamieński (1925), and Samsonowicz (1925), amongst other researchers before Warld War II in addition to e.g. Pożaryski (1962), in-

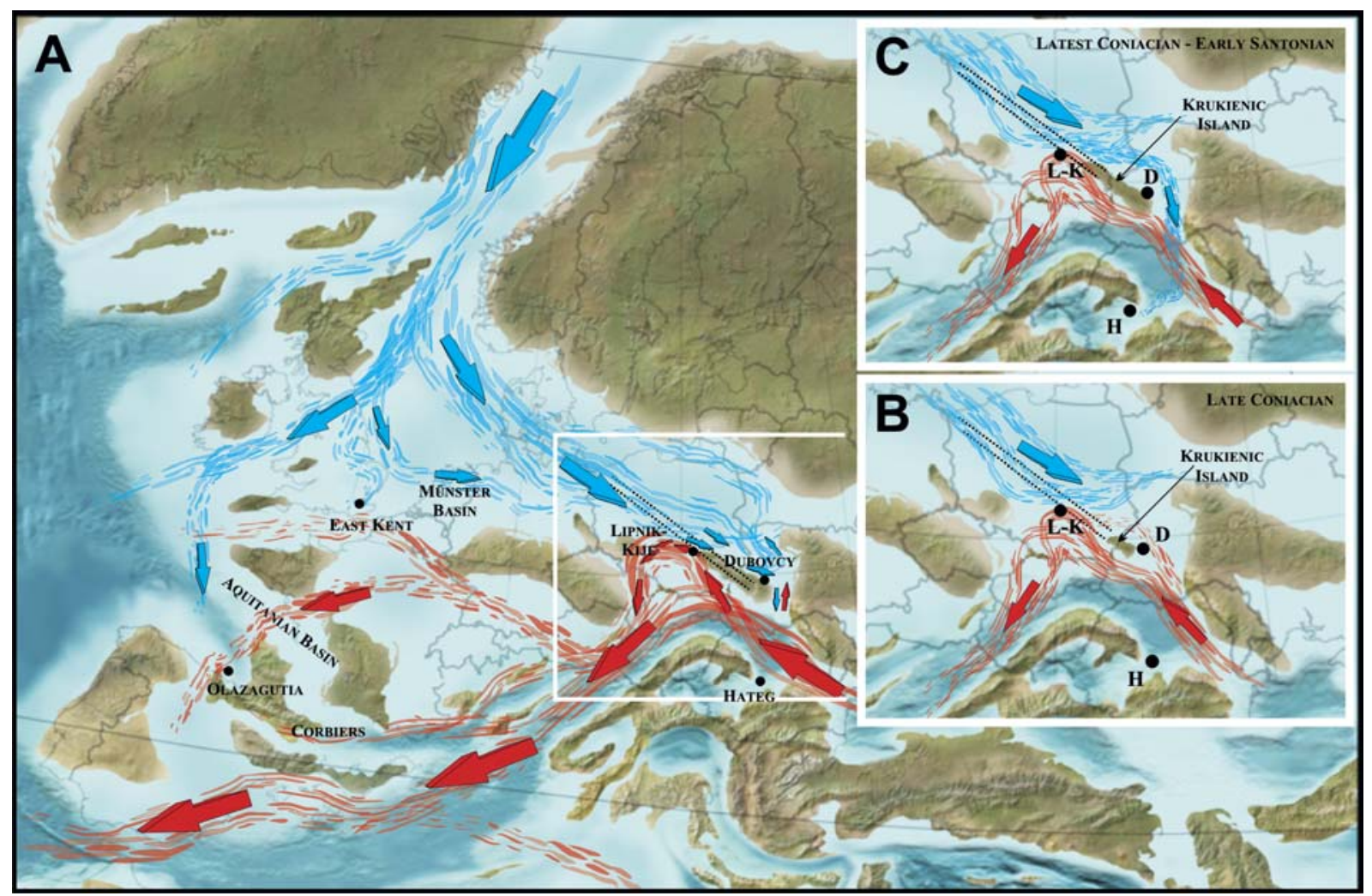

Text-fig. 10. Proposed model of ocean currents (warm - red; cold - blue), which governed the distribution of paleotemperature and cold- and warm-water ammonites. Global paleogeography at the time of Coniacian-Santonian transition showing the distribution of cold Arctic oceanic currents passing through the English Sea (East Kent - EK, Jenkyns et al. 1994), and reaching lower latitudes of the Spanish seas (Olazagutia - Ol, Lamolda and Paul 2007) and the area of Romania, Hateg (Fizesti) - H, Melinte-Dobrinescu and Bojar 2010). To a lesser extent, the cold currents affected the Polish Sea (Lipnik-Kije - LK, this paper) and are most pronounced in the Ukraine (Dubovcy, this paper). Dashed lines indicate the general position of the Mid-Polish Anticlinorium; B-C - paleogeographic changes in the end Coniacian (B) and Early Santonian $(\mathrm{C})$; note the expansion of the Krukienic Island in this time interval and cold currents that reached the Hateg area. Paleogeographic map by Ron Blakey, NAU Geology (www.cpgeosystems.com/75_Cret_EurMap_sm.jpg) 
terpreted the SE part of Poland as an emerged area (Łysogóry-Dobruga Land), which Pasternak (1959) called the Krukienic Island (Krukienickii Ostriv). This land would have been located between LipnikKije and Dubovcy (Text-fig. 10), and would have expanded during Santonian and younger times (Remin et al. 2015; Walaszczyk and Remin 2015; Remin, Z unpublished data).

A distinct facies change from pure opoka-type limestone to dark marls of early Santonian age, is observed in the Dubovcy section (Text-fig. 3). This can be linked to the input of clay and coarser terrigenous material coming from the erosion of Krukienic Island (Text-fig. 10). This morphological and paleobiogeographical barrier, partially emerged and most likely partially subaquaeous (towards the NW) would have rebuilt the paleoceanographic architecture in this part of Eurpe and affected paleo-circulation. In particular the area of western Ukraine would have been cut-off from Tethyan influences allowing cold currents to flow from the North (Text-fig. 10). A similar facies change is observed in the Lipnik-Kije section in the middle Middle Santonian, suggesting that the uplift front moved towards the NW reaching the Holy Cross Segment distinctly later than in Ukraine.

Early Santonian ammonite assemblages from areas in southern Europe are typically included into the Tethyan Realm, such as those represented by the Olazagutia section in northern Spain or Corbieres, southern France (Kennedy et al. 1995). They differ markedly in specific and generic composition from those areas located in northern Europe, such as the Münsterland Cretaceous Basin in northern Germany (Lommerzheim 1995; Kennedy and Kaplan 2000; Kaplan and Kennedy 2000).

At the Coniacian-Santonian boundary both in southern Tethyan and northern Boreal Europe, a distinct change in ammonite fauna is observed (i.e., Kennedy et al. 1995; Remin 2010). In Corbieres (Text-fig. 10), the base of the Santonian is marked by the entry of the representatives of the genera Nowakites, Parapuzosia and Saghalinites, which are widely distributed in the Tethyan Realm and are almost absent in the North European sections commonly connected with the Boreal Realm (Remin 2010). In contrast, in the Münsterland Cretaceous Basin (Text-fig. 10) the acanthoceratid-dominated fauna of latest Coniacian age, is replaced, at the Coniacian-Santonian transition, by a desmoceratiddominated assemblage represented by the genera Kitchinites Spath, 1922, Hauericeras Grossouvre, 1894 and Tragodesmoceras Spath, 1922 (see Lommerzheim 1995; Kennedy and Kaplan 2000; Kaplan and Kennedy 2000).
These patterns of ammonite succession and distribution have previously led to serious problems with the correlation of sections located in the Boreal and Tethyan realms (Hancock 1991; Kennedy et al. 1995; Kaplan and Kennedy 2000). The problems have been solved by the discovery of mixed Tethyan and Boreal assemblages in the Lipnik-Kije section in central Poland, enabling the correlation of so far uncorrelatable sections of northern and southern Europe as well as of other regions (Remin 2010). In this respect, the Lipnik-Kije section, having eight taxa in common with the Boreal Münsterland Cretaceous Basin and 13 taxa in common with the Tethyan Corbieres area (Remin 2010), is one of the most important Coniacian/Santonian sections, providing a unique insight into the paleobiogeography and distribution pattern of ammonites across Europe. The LipnikKije section is characterized by mixed Boreal and Tethyan ammonite assemblages from the Middle/Late Coniacian up to at least the middle Middle Santonian (Remin 2010). In contrast, the Dubovcy section is dominated by Tethyan ammonites in the Late Coniacian which disappear close to the Coniacian-Santonian boundary, followed by the entry of typically Boreal representatives of the Kitchinites group. Higher up in the succession, a consecutive decline in abundance of all cephalopods is observed.

It is generally accepted that climate and ocean water paleotemperature is one of the most important factors influencing ammonite paleobiogeography (e.g. Kennedy and Cobban 1976; Marcinowski and Wiedmann 1988, 1990). The abundance of low-latitude Tethyan ammonites in the Lipnik-Kije area, especially of the genera Nowakites, Parapuzosia and Saghalinites, mixed with the Boreal ammonite of the Kitchinites group in the Early Santonian suggests broad and wide-open connections between the warmer Tethyan and colder Boreal water masses which interacted dynamically in the Polish Sea (Text-fig. 10). In contrast, in Dubovcy, the dominance of Tethyan ammonites in the Middle-Late Coniacian and their general absence in the Early Santonian must have been caused by distinct environmental and/or paleogeographic changes. We speculate that the Dubovcy area must have been cut-off from Tethyan influences in the Early Santonian.

Interestingly, the change in ammonite assemblages in the Dubovcy section occurs simultaneously with the main facies change to a more marly part of the successsion in the Early and Middle Santonian (Text-fig. 3). From the same interval, Dubicka et al. (2014) reported blooms of small buliminids and bolivinids and an increasing number of agglutinated foraminifers indicating oxygen-depleted enviroments and highly eutrophic con- 


\section{ZBYSZEK REMIN ET AL.}

ditions. Additionally, the massive disapearance of selected Tethyan forms of keeled planktonic foraminifera, usually interpreted as warm-water species, were observed in the same interval (compare disscussion in Dubicka et al. 2014). Amongst the few keeled planktonic forms that thrive in the Early and Middle Santonian, only typical Boreal forms are observed (Dubicka et al. 2014).

The expression of the latest Coniacian distinct cooling phase and subsequent warming during the Early Santonian observed in the Dubovcy $\delta^{18} \mathrm{O}$ record, may have resulted from the combination of two factors. The development of the land area (Lysogóry-Dobruga Land known also as Krukienic Island) by tectonic uplift, would have changed the paleo-circulation and allowed the incursion of cold currents from the north during the latest Coniacian. Progressive isolation of this area from Tethyan influences would have prevented faunal mixing in the Early Santonian. This idea is confirmed by ammonite and foraminiferal assemblages, but the gradual trend to more negative $\delta^{18} \mathrm{O}$ values might indicate slight warming after the Coniacian-Santonian cooling event (Text-figs 3 and 9). At the same time the LipnikKije area was still influenced by warmer Tethyan water masses (Text-fig. 10) as indicated by stable, negative $\delta^{18} \mathrm{O}$ values.

The end-Coniacian-earliest Santonian shift to less negative values of $\delta^{18} \mathrm{O}$ (Text-fig. 9) is also evident in the English, Spanish and Romanian sections where cooling is additionally confirmed by nannoplankton evidence. In the GSSP at Olazagutia (Spain) the abundance of low latitude nannoconids sharply decrease just below the Coniacian-Santonian boundary and this is followed in the Early Santonian by the appearance of nannofossils (i.e. Kamptnerius magnificus and Gartnerago segmentatum), abundant at high latitudes (Thierstein 1976). Similar high-latitude nannofloral components coincident with a prounounced increase in $\delta^{18} \mathrm{O}$ values have been detected in the Fizesti section in Romania at the Coniacian-Santonian transition (Melinte-Dobrinescu and Bojar 2010). Mixed Tethyan and Boreal nannofloras were interpreted (Melinte and Lamolda 2002, 2007) as a result of cooler water mass incursion to middle and low paleolatitudes. Alternatively, Lamolda and Paul (2007) hypothesized that the Coniacian-Santonian $\delta^{18} \mathrm{O}$ positive shift reflected global climate changes, or regional fluctuations in the balance between Tethyan and Atlantic water sources leading to the incursion of cooler waters. However, at that time the northern equatorial Atlantic seems to have been typified by warm water masses (Bice et al. 2006) so there appears to be no mechanism for the creation of cold currents at the Coniacian-Santonian boundary.

\section{CONCLUDING REMARKS}

The Lipnik-Kije and Dubovcy sections have been correlated with sections of similar age using $\delta^{13} \mathrm{C}$ and fossil evidence. The $\delta^{13} \mathrm{C}$ shows maximum values around Middle-Upper Coniacian boundary constituting the Kingsdown Isotope Event, whereas the Coniacian-Santonian boundary is defined by the Michel Dean Isotope Event (Text-fig. 8) situated on a longterm fall. This perturbation in the stable carbon isotope record reflected an environmental event on interregional scale and $\delta^{13} \mathrm{C}$ values can be applied successfully as a chemostratigraphic tool for correlation of the base of the Santonian Stage between the distant sedimentary sections.

The proposed paleo-circulation model and paleotemperature distribution across Europe is supported independently by changes in faunal and nannoflora evidence (ammonites, foraminifera and nannoplantkton), combined rather unexpectedly with the bulk $\delta^{18} \mathrm{O}$ data. The Coniacian-Santonian cooling event, resulting from cold currents flowing from the north, is traceable in all studied sections. The cooling produced effects of different scale in different regions (Text-fig. 9). This pattern could have been caused only by the incursion of cool oceanic currents generated at high northern palaeo-latitudes (Text-fig. 10). It is best expressed within the Late Coniacian-Early Santonian in the sections of Dubovcy (Ukraine) and at the Coniacian-Santonian transition in Fizesti (Romania) where is associated with pronounced shift $(\sim+1.0 \%)$ in $\delta^{18} \mathrm{O}$ values followed by gradual warming. As argued by Stoll and Schrag (2000) similar perturbations in Cretaceous $\delta^{18} \mathrm{O}$ values at different localities are more likely to have resulted from climatic fluctuations than from diagenesis.

Our model (Text-figs 9 and 10) explains the enigmatic appearances of late Coniacian - early Santonian Tethyan ammonites (Nowakites, Parapuzosia and Saghalinites) mixed with Boreal cold water Kitchinites group fossils in the Polish sea (Text-fig. 10; Remin 2010). The existence of a tectonically-induced morphological barrier, most likely emerged in Ukraine and SE Poland (Krukienic Island) and perhaps partially subaquaeous towards to the NW, played an important role in the developing paleo-circulation. Connections between the Tethyan Ocean and an epicontinental sea in the area of Dubovcy were progressively hindered either by the uplifted Krukienic Island or the cold currents from the north operated on a much larger scale preventing the ammonite faunas from mixing. Alternatively both of these factors were important. This explains the presence in Dubovce of 
Tethyan ammonites during the Late Coniacian followed by cold-water loving Boreal species during the early Santonian. It is accompanied by significant changes and the disappearance of Tethyan foraminiferal assemblages (compare Dubicka et al. 2014). At Fizesti (Romania), Olazagutia (Spain) and East-Kent (UK), the incursion of cold-water masses is indicated by the appearances of selected species of cold nannoplankton (Lamolda and Paul 2007; Melinte-Dobrinescu and Bojar 2010). The paleoceanographic story proposed above can thus be narrated without the oxygen isotope data. Nevertheless, bulk $\delta^{18} \mathrm{O}$ data, although diagenetically altered, support the paleocirculation model indicating that the studied samples retain some signatures of paleotemperature. The precise origins of the cool northern waters remain problematic.

\section{Acknowledgments}

Thanks go to Irek Walaszczyk (University of Warsaw) for valuable discussions. Joanna Roszkowska-Remin (Polish Geological Institute) for help in the field. Many thanks go to, Markus Wilmsen and an anonymous reviewer for valuable comments on the earlier version of the manuscript. The Polish National Science Centre [grant no. N N307 226539] and The Faculty of Geology of the University of Warsaw is acknowledged for the financial support during the study.

"Regrettably Michał Gruszczyński (1952-2011) passed away before publication of this work. Thank you Michał for your beautiful mind, thank you for being our teacher and unforgettable friend..., Yours..."

\section{REFERENCES}

Arthur, M.A., Dean, W.E. and Schlanger, S.O. 1985. Variations in the global carbon cycle during the Cretaceous related to climate, volcanism, and changes in atmospheric $\mathrm{CO}_{2}$. In: E.T. Sundquist and W.S. Broecker (Eds), The Carbon Cycle and Atmospheric $\mathrm{CO}_{2}$ : Natural Variations, Archaean to Present, 504-529. Geophysical Monograph Series, 32, 627 pp. AGU. Washington, D.C.

Arthur, M.A., Jenkyns H.C., Brumsack H.J. and Schlanger S.O. 1990. Stratigraphy, geochemistry and paleoceanography of organic-rich Cretaceous sequences. NATO Scientific Series C, 304, 75-119.

Bice, K.L., Birgel, D., Meyers, P.A., Dahl, K.A., Hinrichs, K.U. and Norris, R.D. 2006. A multiple proxy and model study of Cretaceous upper ocean temperatures and atmospheric $\mathrm{CO}_{2}$ concentrations. Paleoceanography, 21; PA2002, doi:10.1029/2005PA001203.
Blakey, R.C. 2015. Global Map of the Late Cretaceous. http://cpgeosystems.com/75moll.jpg.

Coplen, T.B. and Schlanger, S.O. 1973. Oxygen and carbon isotope studies of carbonate sediments from site 167, Magellan Rise, LEG 17. In Winterer E.L., Ewing, J.I. et al., (Eds), Initial Reports of the Deep Sea Drilling Project, 17, 505-509. Washington DS. (U.S. Government Printing Office).

Dubicka, Z. Peryt, D. and Szuszkiewicz, M. 2014. Foraminiferal evidence for paleogeographic and paleoenvironmental changes across the Coniacian-Santonian boundary in western Ukraine. Palaeogeography, Palaeoclimatology, Palaeoecology, 401, 43-56.

Gale A.S., Kennedy W.J., Voigt S. and Walaszczyk I. 2005. Stratigraphy of the Upper Cenomanian-Lower Turonian Chalk succession at Eastbourne, Sussex, UK: ammonites, inoceramid bivalves and stable carbon isotopes. Cretaceous Research, 26, 460-487.

Gale, A.S., Kennedy, W.J., Lees, J.A., Petrizzo, R.M. and Walaszczyk. I. 2007. An integrated study (inoceramid bivalves, ammonites, calcareous nannofossils, planktonic foraminifera, carbon stable isotopes) of the Ten Mile Creek section, Lancaster, Dallas County, north Texas, a candidate Global boundary Stratotype Section and Point for the base of the Santonian Stage. Acta Geologica Polonica, 57, 113-160.

Gavrilishin, V.I., Pasternak, S.I. and Rozumeyko, S.V. 1991. Stratigraficheskiye podrazdeleniya melovykh otlozhemiy platformennoy chasti zapada Ukrainy. Akademia Nauk USSR, Institute Geologii i Geokhimii Goryuchikh Iskopayemykh, Lviv, 1-91.

Gruszczyński, M., Coleman, M.L., Marcinowski, R., Walaszczyk. I and Isaacs, M.C. 2002. Palaeoenvironmental conditions of hardgrounds formation in the Late Turonian-Coniacian of Mangyshlak Mountains, western Kazakhstan. Acta Geologica Polonica, 52, 423-435.

Hancock, J.M. 1991. Ammonite time scales for the Cretaceous System. Cretaceous Research, 12, 259-291.

Hudson, J.D. 1977. Stable Isotopes and limestone lithification. Journal of the Geological Society of London, 133, 637660.

Huber, B.T., Hodell, D.A. and Hamilton, C.P. 1995. MiddleLate Cretaceous climate of the southern high latitudes; stable isotopic evidence for minimal equator-to-pole thermal gradients. Geological Society of America Bulletin, 107, 1164-1191.

Ivannikov, A.V., Lipnik, L.F., Plotnikova, L.F., Blank, M.Y., Gavrilishin, V.I. and Pasternak, S.I. 1987. Novye mestnye stratigraficheskiye podrazdeleniya verkhnego mela platformennoy Ukrainy, pp. 41-87. Akademia Nauk USSR, Institut Geologiceskich Nauk; Kiev.

Jacobs, L.L., Ferguson, K., Polcyn, M.J and Rennison, C. 2005. Cretaceous $\delta^{13} \mathrm{C}$ stratigraphy and the age of 


\section{ZBYSZEK REMIN ET AL.}

dolichosaurs and early mosasaurs. In: A.S. Schulp, and J.W.M. Jagt $(E d s)$ : Proceedings of the First Mosasaur Meeting. Netherlands Journal of Geosciences - Geologie en Mijnbouw, 84, 257-268.

Jarvis, I., Gale,.. Jenkyns, H.C. and Pearce, M.A. 2006. Secular variation in Late Cretaceous carbon isotopes: a new $\delta^{13} \mathrm{C}$ carbonate reference curve A for the Cenomanian Campanian (92.6 - 70.6 Ma). Geological Magazine, 143, 561-608.

Jenkyns, H.C., Gale, A.S. and Corfield, R.M. 1994. Carbonand oxygen-isotope stratigraphy of the English Chalk and Italian Scaglia and its palaeoclimatic siginificance. Geological Magazine, 131, 1-34.

Kamieński, M. 1925. Przyczynek do zanjomości kredy żurawieńskiej. Kosmos, 50, 1408-1425.

Kaplan, U. and Kennedy, W.J. 2000. Santonian ammonite stratigraphy of the Münster Basin, NW Germany. Acta Geologica Polonica, 50, 99-119.

Kennedy, W.J. and Kaplan, U. 2000. Ammonitenfaunen des hohen Oberconiac und Santon in Westfalen. Geologie und Paläontologie in Westfalen, 57, 1-131.

Kennedy, W.J. and Cobban, W.A. 1976. Aspects of ammonite biology, biogeography, and biostratigraphy. Special Papers in Palaeontology, 17, 1-94.

Kennedy, W.J., Bilotte, M. and Melchior, P. 1995. Ammonite faunas, biostratigraphy and sequence stratigraphy of the Coniacian-Santonian of the Corbieres (NW Pyrenees). Bulletin des Centres de Recherches Exploration-Production Elf Aquitaine, 19, 377-499.

Kokoszyńska, B. 1931. O faunie, wykształceniu facjalnemu i stratygrafji cenomanu na Podolu. Sprawozdania Polskiego Instytutu Geologicznego, 4, 627-695.

Krzywiec P., Gutowski J., Walaszczyk I., Wróbel G. and Wybraniec S. 2009. Tectonostratigraphic model of the Late Cretaceous inversion along the Nowe Miasto-Zawichost Fault Zone, SE Mid-Polish Trough. Geological Quarterly, 53, 27-48.

Lamolda, M.A. and Paul, C.R.C. 2007. Carbon and oxygen stable isotopes across the Coniacian/Santonian boundary at Olazagutia, northern Spain. Cretaceous Research, 28, $37-45$.

Lamolda, M.A., Paul, C.R.C., Peryt, D. and Pons, J.M. 2014. The Global Boundary Stratotype and Section Point (GSSP) for the Base of the Santonian Stage, "Cantera de Margas", Olazagutia, Northern Spain. Episodes, 37, 2-13.

Leckie, R.M., Sterzinar, E.M. and Tibert, N.E. 2005. OAE2 and OAE3 in the Western Interior Seaway of North America: Influence of Tectonics, Sea Level, and Climate words missg Late Turonian-Early Campanian Niobrara Cycle. In: International Symposium on Recent Advances in Research on Terestrial and Marine Sequences from the midCretaceous Oceanic Anoxic Events (OAEs), 7-9. Hokaido.
Leszczyński K. 2012. The internal geometry and lithofacies pattern of the Upper Cretaceous-Danian sequence in the Polish Lowlands. Geological Quarterly, 56, 363-386.

Li, X., Jenkyns, H.C., Wang, C., Hu, X., Chen, X., Wei, Y., Huang, Y. and Cui, J. 2006. Upper Cretaceous carbon- and oxygen-isotope stratigraphy of hemipelagic carbonate facies from southern Tibet, China. Journal of the Geological Society, London, 163, 375-382.

Lommerzheim, A.J. 1995. Stratigraphie und Ammonitenfaunen des Santons und Campans im Münsterlander Becken (NW-Deutschland). Geologie und Palaontologie in Westfalen, 40, 1-97.

Marcinowski, R. and Wiedmann, J. 1988. Paleogeographic implications of the Albian ammonite faunas of Poland. In: J. Wiedmann and J. Kullmann, (Eds), Cephalopods - Present and Past, pp. 491-504. Schweizerbartsche Verlagsbuchhandlung; Stuttgart.

Marcinowski, R. and Wiedmann, J. 1990. The Albian Ammonites of Poland. Paleontologia Polonica, 50, 3-94.

Marshall, J.D. 1992. Climatic and oceanographic isotopic signals from the carbonate rock record and their preservation. Geological Magazine, 129, 143-160.

Melinte, M.C. and Lamolda, M.A. 2002. Calcareous nannofossils around the Coniacian/Santonian boundary interval in the Olazagutia section (N. Spain). In: M. Wagreich, (Ed.), Aspects of Cretaceous Stratigraphy and Palaeobiogeography. Österreichische Akademie der Wissenschaften Schriftenreihe Erwissenschaftlichen Kommissionen, 15, 351-364.

Melinte, M.C. and Lamolda, M.A. 2007. Calcareous nannofossil biostratigraphy of the Coniacian/Santonian boundary interval in Romania and comparison with other European regions. Cretaceous Research, 28, 119-127.

Melinte-Dobrinescu, M.C. and Bojar, A.V. 2010. Late Cretaceous carbon- and oxygen isotope stratigraphy, nannofossil events and paleoclimate fluctuations in the Haţeg area (SW Romania). Palaeogeography, Palaeoclimatology, Palaeoecology, 293, 295-305.

Mitchell, S.F., Ball, J.D., Crowley, S.F., Marshall, J.D., Paul, C.R.C., Veltkamp, C.J. and Samir, A. 1997. Isotopic data from Cretaceous chalks and foraminifera: environmental or diagenetic signals? Geology, 25, 691-694.

Nowak, J. 1907. Przyczynek do znajomości kredy LwowskoRawskiego Roztocza. Kosmos, 32, 160-169.

Nowak, J. 1908. Spostrzeżenia w sprawie wieku kredy zachodniego Podola. Kosmos, 33, 279-285.

Nowak, J. 1911. Spostrzeżenia nad rozmieszczeniem kredy mukronatowej i kwadratowej na zachodniem Podolu. Kosmos, 36, 480-486.

Nowak, J. 1913. O kredzie zachodniej części Podola i Wołynia. Sprawozdanie Towarzystwa Naukowego Warszawskiego, 8, 765-803.

Nowak, J. 1914. Jednostki tektoniczne polskich Karpat 
Wschodnich. Towarzystwo dla Popierania Nauki Polskiej, 1-160. Lwów, 1914.

Pasternak, S.I. 1959. Biostratygrafiya kreydovykh vidkladiv Volyno-Podilskoi plyty. Vydavnytstvo Akademii Nauk Ukrainskoi RSR, Kiev, 3-98.

Pasternak, S.I., Gavrylyshyn, V.I., Ginda, V.A., Kotsyubinsky, S.P. and Senkovskyi, Y.M. 1968. Stratygrafia i fauna kredowych vidkladiv zachodu Ukrainy. Naukova Dumka, Kiev, 1-272.

Pasternak, S.I., Senkovskyi, Y.M. and Gavrylyshyn, V.I. 1987. Volyno-Podillya u kreydovomu periodi. Naukova Dumka, Kiev, 3-258.

Pożaryski, W. 1962. Atlas Geologiczny Polski - zagadnienia stratygraficzno facjalne. Zeszyt 10 - Kreda. Instytut Geologiczny; Warszawa.

Pożaryski, W. 1964. Zarys tektoniki paleozoiku i mezozoiku Niżu Polskiego (Outline of Paleozoic and Mesozoic tectonics of Polish Lowlands). Geological Quarterly, 8, $1-32$.

Pożaryski, W. 1974. Tectonics. Part 1. Polish Lowlands. In: Pożaryski, W. (Ed.), Geology of Poland IV, pp. 2-34. Wydawnictwa Geologiczne; Warszawa. [In Polish]

Pożaryski, W. 1997. Tektonika powaryscyjska obszaru świętokrzysko-lubelskiego na tle struktury podłoża. Przegląd Geologiczny, 45, 1265-1270.

Pożaryski, W., Brochwicz-Lewiński, W., Brodowicz, Z., Jaskowiak-Szoenejch, M., Milewicz, J., Sawicki, L. and Uberna, T. 1979. Geological map of Poland and adjoining countries, without Cenozoic formations (without Quaternary in the Carpathians). Wydawnictwa Geologiczne; Warszawa.

Remin, Z. 2004. Biostratigraphy of the Santonian in the SW margin of the Holy Cross Mountains near Lipnik, a potential reference section for extra-Carpathian Poland. Acta Geologica Polonica, 54, 587-596.

Remin, Z. 2010. Upper Coniacian, Santonian, and lowermost Campanian ammonites of the Lipnik-Kije section, central Poland, taxonomy, stratigraphy, and palaeogeographic significance, Cretaceous Research, 31, 154-180.

Remin, Z., Cyglicki, M., Cybula, M. and Roszkowska-Remin, J. 2015. Deep versus shallow? Deltaically influenced sedimentation and new transport directions - case study from the Upper Campanian of the Roztocze Hills, SE Poland. Abstract Book of the 31st IAS Meeting of Sedimentology, 22nd-25th June 2015, p. 438. Kraków.

Rogala, W. 1908. Sprawozdanie z badań geologicznych wzdłóż kolei Lwów - Podhajce. Kosmos, 33, 50-62.

Rogala, W. 1909. O stratygrafii utworów kredowych Podola. Kosmos, 34, 1160-1164.

Rogala, W. 1910. O utworach kredowych wzdłóż północnego brzegu Podola. Kosmos, 35, 1013-1023.

Rogala, W. 1911. Przyczynek do znajomości mukronatowej kredy okolic Lwowa. Kosmos, 36, 487-499.
Samsonowicz, J. 1925. Szkic geologiczny okolic Rachowa nad Wisłą oraz transgresje albu i cenomanu w bróździe północno-europejskiej. Sprawozdania Polskiego Instytutu Geologicznego, 3, 45-98.

Schlanger S.O, Arthur M., Jenkyns H.C and Scholle P.A. 1987. The Cenomanian-Turonian Oceanic Anoxic Event, I. Stratigraphy and distribution of organic-rich beds and the marine $\delta^{13} \mathrm{C}$ excursion. Geological Society London Special Publications Journal, 26, 371-399.

Scholle, P.A. and Arthur, M.A. 1980. Carbon isotope fluctuations in Cretaceous pelagic limestones: potential stratigraphic and petroleum exploration tool. American Association of Petroleum Geologists Bulletin, 64, 67-87.

Stoll, H.M. and Schrag, D.P. 2000. High-resolution stable isotope records from the Upper Cretaceous rocks of Italy and Spain: glacial episodes in a greenhouse planet? Geological Society of America Bulletin, 112, 308-319.

Svabenicka, L. 1995. Common occurrences of the ecologically restricted nannofossils in the Campanian sediments of the Zdanice Unit and Waschburg Zone, West Carpathians. Geological Society of Greece, Special Publication, 4, 282-287.

Świdrowska, J., Hakenberg, M., Poluthović, B., Seghedi, A. and Višnâkov, I. 2008. Evolution of the Mesozoic basins on the south western edge of the East European Craton (Poland, Ukraine, Moldova, Romania). Studia Geologica Polonica, 130, 3-130.

Thierstein, H.R. 1976. Mesozoic calcareous nannoplankton biostratigraphy of marine sediments. Marine Micropaleontology, 1, 325-362.

Vashchenko, V.O., Turchynova, S.M., Turchynov, I.I. and Polikha, G.G. 2007. Derzhavna geologichna karta Ukrainy, masshtab 1:200 000, Karpatska seria. Arkush M-35-XXV (Ivano-Frankivsk). Poyasniuvalna zapiska, Kyiv.

Voigt, S. and Hilbrecht, H. 1997. Late Cretaceous carbon isotope stratigraphy in Europe: correlation and relations with sea level and sediment stability. Palaeogeography, Palaeoclimatology, Palaeoecology, 134, 39-59.

Voigt, S. and Wiese, F. 2000. Evidence for late Cretaceous (Late Turonian) climate cooling from oxygen-isotope variations and palaeobiogeographic changes in Western and Central Europe. Journal of Geological Society, 157, 737-743.

Voigt, S. 2000. Cenomanian-Turonian composite $\delta^{13} \mathrm{C}$ curve for Western and Central Europe: the role of organic and inorganic carbon fluxes. Palaeogeography, Palaeoclimatology, Palaeoecology, 160, 91-104.

Walaszczyk, I. 1992. Turonian through Santonian deposits of the Central Polish Uplands; their facies development, inoceramid paleontology and stratigraphy. Acta Geologica Polonica, 42, 1-122.

Walaszczyk, I. and Remin, Z. 2015. Kreda obrzeżenia Gór 


\section{ZBYSZEK REMIN ET AL.}

Świętokrzyskich. In: Stanisław Skompski i Włodzimierz Mizerski (Eds), Ekstensja i Inwersja Powaryscyjskich Basenów Sedymentacyjnych; LXXXVI Zjazd Naukowy Polskiego Towarzystwa Geologicznego, pp. 41-50.

Zapata, E., Padron, V., Madrid, I., Ketznus, V., Truskowski, I. and Lorente, M.A. 2003. Biostratigraphic, sedimentologic, and chemostratigraphic study of the La Luna Formation (Late Turonian-Campanian) in the San Miguel and Las Hernández Sections, Western Venezuela. Palaios, 18, 367-377.

Manuscript submitted: $24^{\text {th }}$ November 2014

Revised version accepted: $15^{\text {th }}$ November 2015 